\title{
Hydrocarbon prospectivity of the miocene-pliocene clastic reservoirs, Northern Taranaki basin, New Zealand: integration of petrographic and geophysical studies
}

\author{
Ahmed A. Radwan ${ }^{1,2}$ (D) Bassem S. Nabawy ${ }^{3}$ \\ Received: 10 December 2021 / Accepted: 28 December 2021 / Published online: 7 January 2022 \\ (c) The Author(s) 2022
}

\begin{abstract}
In this study, it is aimed to characterize the Early pliocene sandstone (EP-SD) and the Late Miocene-Early Pliocene Mangaa sandstone reservoirs and the efficiency of their sealing cap rocks using the petrographical and petrophysical data of these sandstone zones in northern Taranaki basin, New Zealand. The prospective potential reservoirs were studied using impregnated thin sections, XRD data analysis, and well log data (self-potential, gamma-ray, sonic, density, neutron, shallowldeep resistivity and PEF) to characterize the reservoir zones, in addition to Mercury intrusion capillary pressure data (MICP) to check the efficiency of some potential seals. The EP-SD and the Mangaa sandstone units are typically poorly consolidated very fine sandstone to siltstone, with porosities averaging $25 \%$. The sands are composed of quartz (38.3-57.4\%), with common feldspars (9.9-15.2\% plagioclase, and 2.7-6.3\% K-feldspars) and up to 31.8\% mica. In Albacore-1 well to the north of the Taranaki Basin, the Mangaa formation includes three separate for each of the EP-SD zones (EP-SD1, EP-SD2, and EP-SD3), and the Mangaa sequence (Mangaa-0, Mangaa-1, and Mangaa-2). The thin section studies indicate that, the studied samples are grouped into greywackes, arenites and siltstone microfacies with much lithic fragments and feldspars, sometimes with glauconite pellets. From the XRD data, it is achieved that the mineral composition is dominated by quartz, mica/illite, feldspars, and chlorite. The petrophysical investigation revealed absence of pay zones in the EP-SD zones, and presence of thin pay zone with net thickness $5.79 \mathrm{~m}$ and hydrocarbon saturation of about $25.6 \%$. The effective porosities vary between 23.6 and $27.7 \%$, while the shale volume lies between 12.3 and $16.9 \%$. Although the shale content is relatively low, the relatively high API (50-112 API of average 75 API) is contributed by the relatively high K-feldspar content and intercalations with thin siltstone and muddy siltstone beds. Sealing units include the intra-formational seals within the Mangaa sequence, mudstones and fine grained units overlying the Mangaa and further intra-formational mudstones, within the shallower EP-SD units. The efficiency of these seals indicates the capability to trap 16.4-40.6 m gas or 17.4-43.0 m oil which is relatively low in correlation with their efficiency in the central parts of the Taranaki Basin Overlying the primary seals, mudstones of the Giant Foresets Formation provide additional regional seal.
\end{abstract}

Keywords Mangaa sandstone $\cdot$ Early pliocene sandstone $\cdot$ Petrography $\cdot$ Taranaki basin $\cdot$ Petrophysics $\cdot$ Hydrocarbon potentiality

Ahmed A. Radwan

ahmedabdelhaleim.ast@azhar.edu.eg

1 Department of Geology, Faculty of Science, Al-Azhar University, Assiut Branch, Assiut, Egypt

2 Institute of Earth Sciences, Southern Federal University, Zorge St., 40, 344090 Rostov-on-Don, Russia

3 Department of Geophysical Sciences, National Research Centre, Dokki, Cairo, Egypt

\section{Introduction}

The Great Taranaki Basin represents one of the largest sedimentary basins along the western coast of New Zealand. The basin is considered the lone hydrocarbon-producing basin in New Zealand; it has an areal extent of about 330,000 $\mathrm{km}^{2}$. It is bounded to the south by the West Coast basins and to the north by Reinga Basin (King and Thrasher, 1996; Funnell et al., 2001; Uruski et al., 2003; Radwan et al., 2021a, 2022b) (Fig. 1). Up to date, more than 400 offshore and onshore exploration and production wells were drilled 


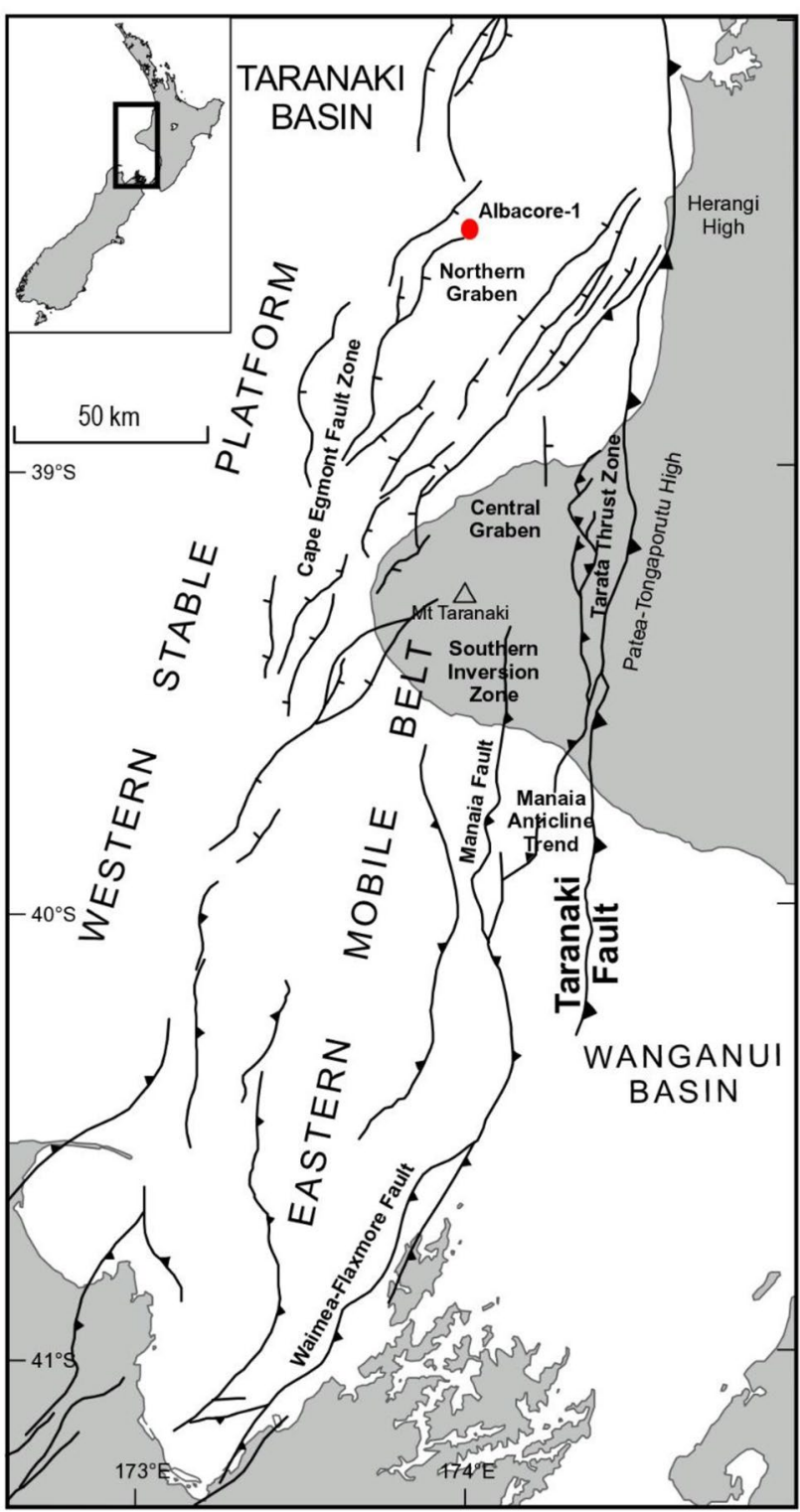

Fig. 1 Map of the Taranaki Basin, showing the main structural elements and the location of the Albacore-1 well

within the Taranaki Basin. However, the Taranaki Basin is still potential for more exploration and discoveries.

The seismic survey indicated the presence of thick sedimentary sequences filling a depocentre for at least $150 \mathrm{~km}$ along the axis of the basin (Sutherland et al, 2001; Uruski et al., 2003). Among these, the Upper Miocene-Lower Pliocene reservoirs in the Taranaki Basin were rarely studied. Thereby, this study concerns with the potentiality and the reservoir quality of the Miocene-Pliocene Mangaa sandstone reservoir which is considered a main gas-bearing target in the basin. The Upper Miocene-Lower Pliocene deep-water Mangaa sandstone is located in the North of Taranaki Basin and attains an average thickness of about $340 \mathrm{~m}$; it is built of very fine sandstones to siltstone of seafloor turbidity fan (King and Thrasher, 1996; Radwan et al., 2022b).

The Mangaa sandstones sequence of the offshore Albacore-1 well in North Taranaki is chosen as a case study for the reservoir characterization of the Mangaa Formation in this basin. These sandstones are fine to medium-grained, poorly consolidated, and are highly porous of porosity values varying from place to place of average $27.5 \%$ (Radwan et al., 2022b).

The studied Albacore-1 well has been drilled through a Miocene-Pliocene structural trend associated with some volcanics and volcaniclastics. The Mangaa sandstones in this well can be separated into three separate seismic units; these are named Mangaa-0, Mangaa-1 and Mangaa-2.

A detailed reservoir characterization and quality assessment can be achieved using integration between the petrographical (thin sections, SEM and XRD data) and the pertrophysical (core and well log data) studies have been widely used by many authors in different basins worldwide (Harrison and Dutton, 1991; Abd El-Gawad, 2007; Makhloufi et al., 2013; Chihi et al., 2013; Shalaby et al., 2013, 2014; Ghanizadeh et al., 2015; Nabawy et al., 2015; El Sharawy and Nabawy, 2016, 2018; Jadoon et al., 2016; Azeem et al., 2017; Benaafi et al., 2018; Nabawy et al., 2018a, 2018b, 2020a; Abuamarah et al., 2019; Radwan et al., 2021a, b, 2022a, b; Abdelwahhab et al., 2022). Therefore, the main target of the present study is to characterize the Mangaa reservoir in Taranaki Basin using integration between petrographical, and petrophysical well logs and core data.

\section{Geologic setting}

The Taranaki basin is one of the most important hydrocarbon-prospective sedimentary basins in the offshore of New Zealand. It is named after the Pleistocene Mount Taranaki volcano that forms the main parts of the Taranaki Peninsula which is surrounded by most of the oil and gas fields in New Zealand (King and Thrasher, 1996; Uruski and Wood, 1991; Uruski, 2000). Up to $90 \%$ of its extension is offshore, whereas only the Taranaki Peninsula and the Northwest Nelson area are located onshore (Isaac et al., 1994; Uruski et al., 2003). The onshore Taranaki Basin is primarily overlain by the Pleistocene Mount Taranaki andesite, the Kaitake, and the Pouakai ranges. It is bounded to the east by the Taranaki Fault and the Wanganui Basin (Radwan et al., 2022b) (Fig. 1). The main Taranaki Fault is considered the largest structural compressional feature within this area. It has shown remarkable activities during various episodes. Its most recent reactivation has been caused by the convergent movements that have been driven by the modern plate boundary development. The Neogene deposits extend to the east crossing the main Taranaki fault and merging with the 
Wanganui and King basins. Besides, the western boundary of the Taranaki Basin is generally considered as a shelf break merging into the New Caledonia Basin.

The Taranaki Basin is divided into two parts; an Eastern Mobile Belt and a Western Stable Platform. The Eastern Mobile Belt is a part of the Australian plate that has been deformed by the colliding between the Pale and the Pacific plate. Its complex morphology is due to its modification by many tectonic episodes including the Neogene marginrelated convergent events and the early rift-drift phase (King and Thrasher, 1996; Radwan et al., 2022b).

The Late Pliocene event reflects the present-day crustal geometry, where the Late Miocene phase indicates the start-up and geometry the present day tectonic setting of the Taranaki Basin (Knox, 1982).

Throughout the depositional history of Taranaki Basin, its predominant paleo-environments in the eastern and the southern portions were affected a complex eustatic and tectonic interplay, while the western and the northern areas retained connected to the sea (Palmer, 1985; King, 2000; Palmer and Geoff, 1991; Radwan et al., 2022b).

The Taranaki basin has been filled by a Cretaceous to Neogene sedimentary cover. In its onshore part, these sediments are overlain by Quaternary alluvial, aeolian, marine deposits, and volcaniclastics (Pilaar and Wakefield, 1978; Knox, 1982; Armstrong et al., 1996). The paleoenvironmental data indicates that these sands were deposited in bathyal environments as turbidites near the base of the Pliocene Foresets slope sequence (Radwan et al., 2022b).

The Miocene sediments in Taranaki Basin represent a set of regressive sequences accumulated in episodes of increasing rates of sediment influx that have been triggered by the tectonic events, where clastics reworked from the uplifted areas in the vicinity with large volumes and accumulated in the centre of the basin depocentre. Upwards, the Pliocene-Pleistocene sedimentary deposits in the Taranaki Basin comprising the Giant Foresets, Matemateaonga, Tangahoe, and Mangaa formations (King, 1988). In general, the sedimentary sequence of the Taranaki Basin is primarily regressive and controlled by the detrital supply volumes and the interplay between the tectonic subsidence and the sediment influx. The Mangaa sandstone and the Giant Foresets sequences are composed of deep water fan sandstone alternated with a slope channel sandstone turbidites and basin floor shale the basin floor (Radwan et al., 2022b).

In the present case study, the Mangaa sandstone is divided into three units in the Albacore-1 well: (1) Mangaa-0 sand that is encountered at interval 1779-1924 m, (2) Mangaa-1 sand at depth interval 1924-2044 m, and (3) Mangaa-2 sand at depth interval 2044-2121 m. Besides, the Early Pliocene sandstone (EP-SD) is divided into other three units: (1) EP-SD1, (2) EP-SD-2, and (3) EP-SD3. A generalized sketch for the lithostratigraphy sequence of the Taranaki Basin is presented in Fig. 2.

\section{Data and methodology}

The present study aims at characterizing the Mangaa sandstone in Taranaki Basin by utilizing different data sets including petrographic, and petrophysical data. Thereby, the Albacore-1 well which has complete data sets was chosen as a case study for characterizing the Mangaa sandstone.

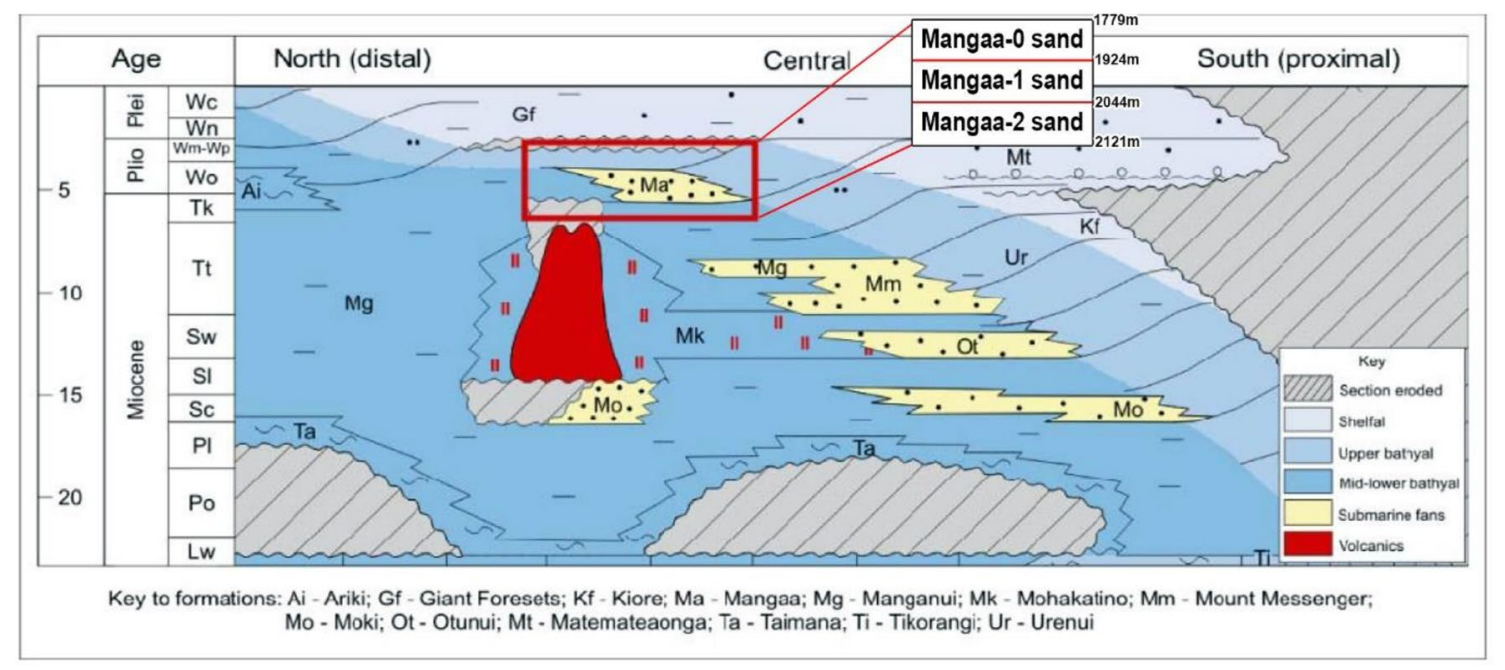

Fig. 2 A generalized stratigraphic column of the Neogene sediments in the Taranaki Basin (King and Thrasher, 1996). The Mangaa sandstone, the core of the present study, is outlined by a red box 


\section{Petrographic studies}

For the petrographical studies, ten samples were selected, and slabbed, representatively for the Mangaa sandstone in the Albacore-1 well. To describe the different pore types and to assess the visual porosity rough estimation, the prepared slabs were impregnated by a blue-dyed epoxy. These slabs were then prepared as thin sections and then the visual porosity and the main mineral components were estimated using a polarized microscope supplied with a PC monitor enabling a detailed estimation for the different mineral constituents.

Also, the diagenetic features and the grain-to-grain relationships were defined. The longest dimension of 100 grains/ thin section was measured using a grain size comparator and then the grain size and sorting degree were accurately estimated.

Besides, a semi-quantitative estimate of the overall mineral composition of the studied samples (grinded into very fine size) was determined precisely for the whole rock and clay fraction $(<2 \mu \mathrm{m})$ using the X-ray diffractometer (XRD) with a scanning speed of $0.01 \%$ sec in the range of $2 \theta=5-85^{\circ}$ at $40 \mathrm{kV}$.

The mineral composition of eight samples of the probable reservoir zones (EP-SD-1, EP-SD2, EP-SD3, Mangaa-0, Mangaa-1, and Mangaa-2) were examined using the X-ray diffraction (XRD) analysis. In combination, these two analyses give a quantitative estimate of the overall mineralogy of the samples. The mineralogy, estimated from the XRD data, is for each sample as a whole, so the identified mineral composition is for the main rock sample constituents and also for the multi-mineral lithic fragments, not necessarily for the rock sample itself.

\section{Well log analysis}

To examine the Early Pliocene and the Mangaa sandstone reservoir properties and to define the prospective flow units, net-pay thickness, lithology, porosity, shale volume, and the overall fluid types and saturation, a log-based petrophysical analysis has been carried out on the available well logging data of the Abacore-1 well.

For the present study, a complete set of conventional well log data was available including Gamma-ray (GR), Selfpotential (SP), neutron (NPHI), density (RHOB), photoelectric factor (PEF), sonic (DT), and resistivity logs (shallow and deep resistivity, LLS and LLD, respectively). To carry out the quantitative and qualitative reservoir evaluation, the las files of these logs were imported into the Interactive Petrophysics software (IP 4.5) of Senergy Co. Then, the sand zones were defined and separated from the shaly zones. The petrophysical analysis was performed using the relevant equations and standard procedures that have been published by many authors (e.g., Archie, 1942; Poupon et al., 1970; Asquith, 1985).

Lithology and the mineral composition of the Mangaa sandstone were estimated using the $\mathrm{M}-\mathrm{N}$ cross-plot, where the $\mathrm{M}$ and $\mathrm{N}$ values can be calculated using the following equations.

$M=\left(\Delta t_{F}-\Delta t_{M}\right) /\left(\rho_{M}-\rho_{F}\right)$

$N=\left(\emptyset_{N F}-\emptyset_{N M}\right) /\left(\rho_{M}-\rho_{F}\right)$

where $\Delta \mathrm{t}_{\mathrm{F}}$ and $\Delta \mathrm{t}_{\mathrm{M}}=$ the sonic log readings for the fluid and matrix, respectively,

$\rho_{\mathrm{F}}$ and $\rho_{\mathrm{M}}=$ the fluid and matrix densities, respectively; and.

$\varnothing_{\mathrm{NF}}$ and $\varnothing_{\mathrm{NM}}=$ the neutron porosity for both the fluid and matrix, respectively.

The density-neutron combination was used for calculating the total porosity $\left(\varnothing_{\mathrm{T}}\right)$ values, whereas the effective porosity $\left(\varnothing_{\mathrm{e}}\right)$ was calculated by eliminating the shale volume share from the total porosity.

The total porosity was estimated utilizing the density and neutron log values (Schlumberger, 1991; Islam, 2010; Nabawy and Shehata, 2015; Tiab and Donaldson, 2015) as follows.

$\varnothing_{T}=\sqrt{ }\left(\varnothing_{D}^{2}+\varnothing_{N}^{2}\right)$

where

$\varnothing_{D}=\frac{\rho_{m a}-\rho_{b}}{\rho_{m a}-\rho_{f}}$

where $\varnothing_{\mathrm{N}}=$ the apparent neutron porosity, $\varnothing_{\mathrm{D}}=$ the density porosity, $\rho_{\mathrm{ma}}=$ the matrix density, $\rho_{\mathrm{b}}=$ the bulk density, and $\rho_{\mathrm{f}}=$ the fluid density.

Besides, the effective porosity was estimated as the total porosity corrected for the shale volume (Schlumberger, 1989) as follows.

$\varnothing_{e}=\varnothing_{T} \times\left(1-V_{s h}\right)$

The shale volume was estimated using a single-log method (gamma-ray), where the shale parameters that were applied to the Early Pliocene and the Mangaa sandstone reservoir are the sonic transit time $\left(\Delta \mathrm{t}_{\mathrm{sh}}=100 \mu \mathrm{s} / \mathrm{ft}\right)$, electric resistivity $\left(\mathrm{R}_{\mathrm{sh}}=2.0 \Omega . \mathrm{m}\right)$, neutron porosity $\left(\varnothing_{\mathrm{Nsh}}=39 \%\right)$, and the bulk density of shale $\left(\rho_{\mathrm{sh}}=2.39 \mathrm{~g} / \mathrm{cm}^{3}\right)$. Then, the corrected shale volume $\left(\mathrm{V}_{\mathrm{sh}}\right)$ was estimated using Larionov's Eq. (1969).

$V_{s h}=0.083 \times\left(2^{3.7 I_{s h}}-1\right)$

where $I_{\text {sh }}=$ gamma-ray index which is estimated as using the Asquith and Gibson formula (1982) as follows. 
$I_{s h}=\left(G R_{\text {log }}-G R_{\min }\right) /\left(G R_{\max }-G R_{\min }\right)$

where $\mathrm{GR}_{\log }=$ the gamma-ray log reading at a given depth, as the $\mathrm{GR}_{\max }$ and $\mathrm{GR}_{\text {min }}$ are the maximum and the minimum gamma-ray readings, respectively, through the logged zones.

The water saturation ( $\mathrm{Sw}$ ) was estimated using the Indonesian equation of Poupon and Leveaux (1971).

$S_{w}=\left\{\left[\left(\frac{V_{s h}^{2-V_{s h}}}{R_{s h}}\right)^{1 / 2}+\left(\frac{\phi_{e}^{m}}{R_{w}}\right)^{1 / 2}\right]^{2} R_{t}\right\}^{-1 / n}$

where $\mathrm{R}_{\mathrm{t}}=$ the formation true resistivity, $\mathrm{V}_{\mathrm{sh}}=$ is the shale volume, $\mathrm{R}_{\mathrm{sh}}=$ shale resistivity, $\varnothing_{\mathrm{e}}=$ effective porosity, $\mathrm{R}_{\mathrm{w}}=$ formation water resistivity, $\mathrm{m}=$ the porosity exponent, and $\mathrm{n}=$ the saturation exponent.

The formation water resistivity ( $\mathrm{Rw}$ in ohm.m) and the porosity exponent $(\mathrm{m})$ were estimated using the Pickett cross-plot (Pickett, 1972) by plotting the porosity values versus their corresponding deep resistivity $\left(\mathrm{R}_{\mathrm{t}}\right)$ at the measuring levels. Based on this plot, the Rw was calculated as $0.098 \Omega . \mathrm{m}$ at $45^{\circ} \mathrm{C}$ formation temperature.

To determine the net-pay thickness, the reservoir and non-reservoir intervals were discriminated from each other considering the porosity, shale volume and water saturation cut-off values, where $15 \%$ effective porosity was applied as a cut-off value, whereas $35 \%$ and $75 \%$ were applied as cut-off values for the shale volume and the water saturation.

\section{Seal capacity}

For measuring the seal capacity of the cap rocks overlying the Early Pliocene and the Mangaa sandstone, the pore throat distribution of six samples was measured using the Mercury injection capillary pressure technique (MICP). These samples were selected representatively for the different seals above the probable reservoir horizons (EP-SD1, EP-SD2, EP-SD3, Mangaa 0, Mangaa 1 and Mangaa 2 at depths 1260, $1510,1588,1777,1918,2035 \mathrm{~m})$. In addition, two samples were selected representatively for the fine grained muddy siltstone lithofacies within the reservoir units (EP-SD3 and Mangaa 0 at depths 1655 and 1837, respectively).

To measure the seal capacity, eight samples were measured using the Mercury intrusion capillary pressure (MICP) technique. Then, the air-mercury capillary pressure data that has been measured at the lab conditions $\left(\mathrm{Pc}_{\mathrm{L}}\right)$ was converted to the oil-water and gas-water dual systems at the reservoir conditions $\left(\mathrm{Pc}_{\mathrm{R}}\right)$. Then, the equivalent gas and the oil columns were estimated at four points of mercury saturation $(0,5.0,7.5$, and $10 \%$ mercury saturation). For estimating the hydrocarbon columns, the gas density $=0.19 \mathrm{~g} / \mathrm{cm}^{3}$, oil density $=0.75 \mathrm{~g} / \mathrm{c} \mathrm{m}^{3}$, and water density $=1.05 \mathrm{~g} / \mathrm{c} \mathrm{m}^{3}$, gas $/$ water surface tension $=50$ $\mathrm{dyn} / \mathrm{cm}$, and the oil-water interfacial tension $=30 \mathrm{dyn} / \mathrm{cm}$ were considered. The seal capacity or the hydrocarbon column thickness or height above the free water or oil level was calculated at the aforementioned four mercury saturation points, each with its corresponding $\mathrm{Pc}_{\mathrm{R}}$ values using the seal capacity equations of Hannon (1987). It is also required to know a number of other variables, such as the water and hydrocarbon pressure gradients in the reservoir ( $\mathrm{Gw}$ and $\mathrm{GH}$, respectively), and the interfacial tension and contact angles at the reservoir and the laboratory conditions (Vavra et al., 1992). As these variables are not known with any confidence in this study, the input values for these variables were taken from another publication on the Mangaa sandstone sequence (Awatea-1 well; Murray and de Bock, 1996).

$P c_{R}=P c_{L} x(s . \operatorname{Cos} q)_{R} /(s . \operatorname{Cos} q)_{L}$

$H c=P c_{R} /\left(G_{W}-G_{H}\right)$

where $\mathrm{Pc}_{\mathrm{R}}$ is the capillary pressure taken at reservoir conditions,

$\mathrm{Hc}$ is the hydrocarbon height/column in the reservoir below the seal rock (in $\mathrm{m}$ ).

$\mathrm{PcL}$ is the threshold capillary pressure measured at the laboratory conditions,

$(\sigma \cdot \operatorname{Cos} \theta)_{\mathrm{R}}$ is the interfacial tension multiplied by the contact angle between the hydrocarbons and the water at the reservoir conditions (gas-water $=50$; oil-water $=26$ ),

$(\sigma \cdot \operatorname{Cos} \theta)_{\mathrm{L}}$ is interfacial tension multiplied by the contact angle between the air and mercury at the laboratory conditions (air-mercury $=367$ ),

$\mathrm{G}_{\mathrm{w}}$ is the water pressure gradient $(0.469 \mathrm{psi} / \mathrm{ft})$, and

$\mathrm{G}_{\mathrm{H}}$ is the hydrocarbon pressure gradient $(0.282 \mathrm{psi} / \mathrm{m}$ for oil, and $0.088 \mathrm{psi} / \mathrm{m}$ for gas.

The MICP data were then presented on mercury saturation-pore radius size plot and its rank was estimated following the classification ranks of Nabawy et al. (2018a) (Nabawy and Wassif, 2017; El Sawy et al., 2020; Abuamarah and Nabawy, 2021; Radwan et al., 2022b) and the threshold pressure as the first inflection point on the capillary pressure curve that is followed by a large gradient increase on the incremental pore volume curve following Dewhurst et al. (2002). 


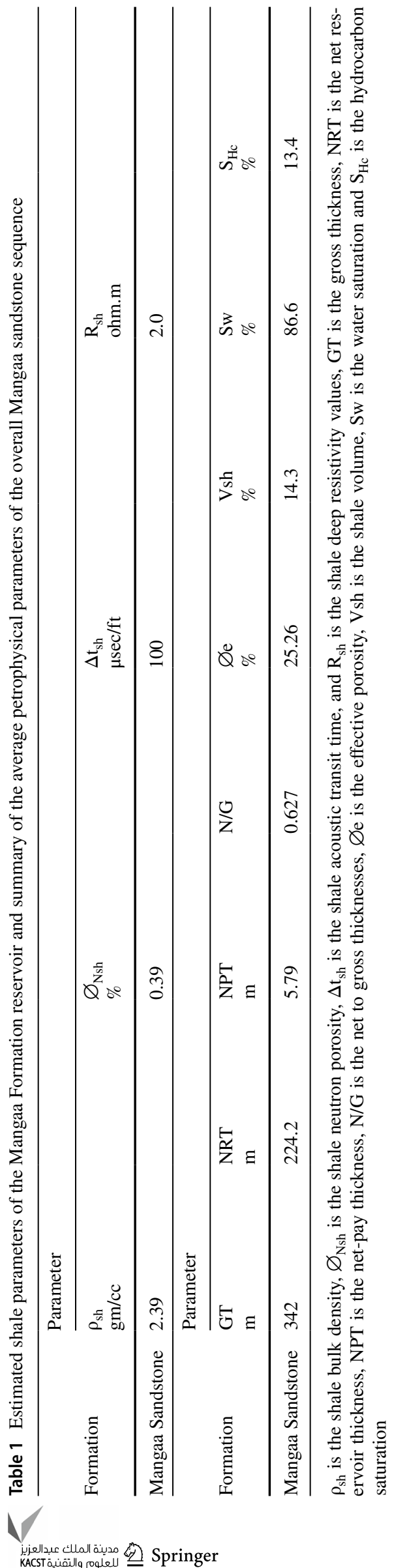

\section{Results and discussion}

\section{Reservoir characterization using well log interpretation}

Due to the gas shows during the well testing processes during the exploration activities in north of the Taranaki Basin, the reservoir characterization of the Early Pliocene and the Mangaa sandstone has been achieved using the well $\log$ analysis and interpretation. It aims at getting an insight into the hydrocarbon potentiality of the Mangaa reservoir and the probable Early Pliocene reservoirs by evaluating its petrophysical characteristics. As explained in the methodology section, to achieve a detailed reservoir characterization the shale parameters of the Mangaa reservoir should be estimated using the cross-plots of the gamma-ray versus the bulk density $\left(\rho_{\mathrm{sh}}\right)$, neutron porosity $\left(\varnothing_{\mathrm{Nsh}}\right)$, acoustic transit time $\left(\Delta \mathrm{t}_{\mathrm{sh}}\right)$, and deep resistivity values $\left(\mathrm{R}_{\mathrm{sh}}\right)$ (Table 1$)$. From the present study, the well $\log$ data of the Early Pliocene and the Mangaa sandstones were plotted as a function of depth (Figs. 3, 4). Based on these plots, it is indicated that though the relatively high porosity values, the Early Pliocene sandstone sequences are composed primarily of siltstone and muddy siltstone with much clay content and no pay zones were assigned due to the high gamma-ray and shale content, and the low resistivity values (Fig. 3). It seems to be just gas pockets which may be evolved from the underneath Mangaa sandstone zones. So, the EP-SD sand zones were excluded from further petrophysical processing and interpretation.

Besides, the average petrophysical parameters of the Mangaa Formation, considering the reservoir intervals of the Albacore-1 well, indicate the presence of about $5.79 \mathrm{~m}$ net-pay thickness of $25.26 \%$ effective porosity, while the shale volume is $14.3 \%$ (Table 1). Although the relatively low shale volume, the API values are primarily higher than $75^{\circ}$ API for the different reservoir zones, which is attributed to a relatively high $\mathrm{K}$-feldspar content and intercalations with siltstone (Table 1) (Molenaar et al., 2015). It is indicated that the Mangaa sandstone attains an average gross thickness of about $342 \mathrm{~m}$ with average net reservoir equals $224.2 \mathrm{~m}$, representing the potential thickness of the producing hydrocarbon, and net-pay thickness equals $5.79 \mathrm{~m}$ (Table 1).

Plotting the different petrophysical parameters of Mangaa Formation in the Albacore-1 well indicates that it can be subdivided into three reservoir units; Mangaa-0, Mangaa-1 and Mangaa- 2 units. Based on this plot, the effective porosity values of the Mangaa Formation vary from $23.6 \%$ in Mangaa-2 sand unit to $27.7 \%$ in the Mangaa- 0 sand unit. Besides, the shale volume values range from $12.3 \%$ in the Mangaa-2 sand unit to $16.9 \%$ in the Mangaa-1 sand unit 


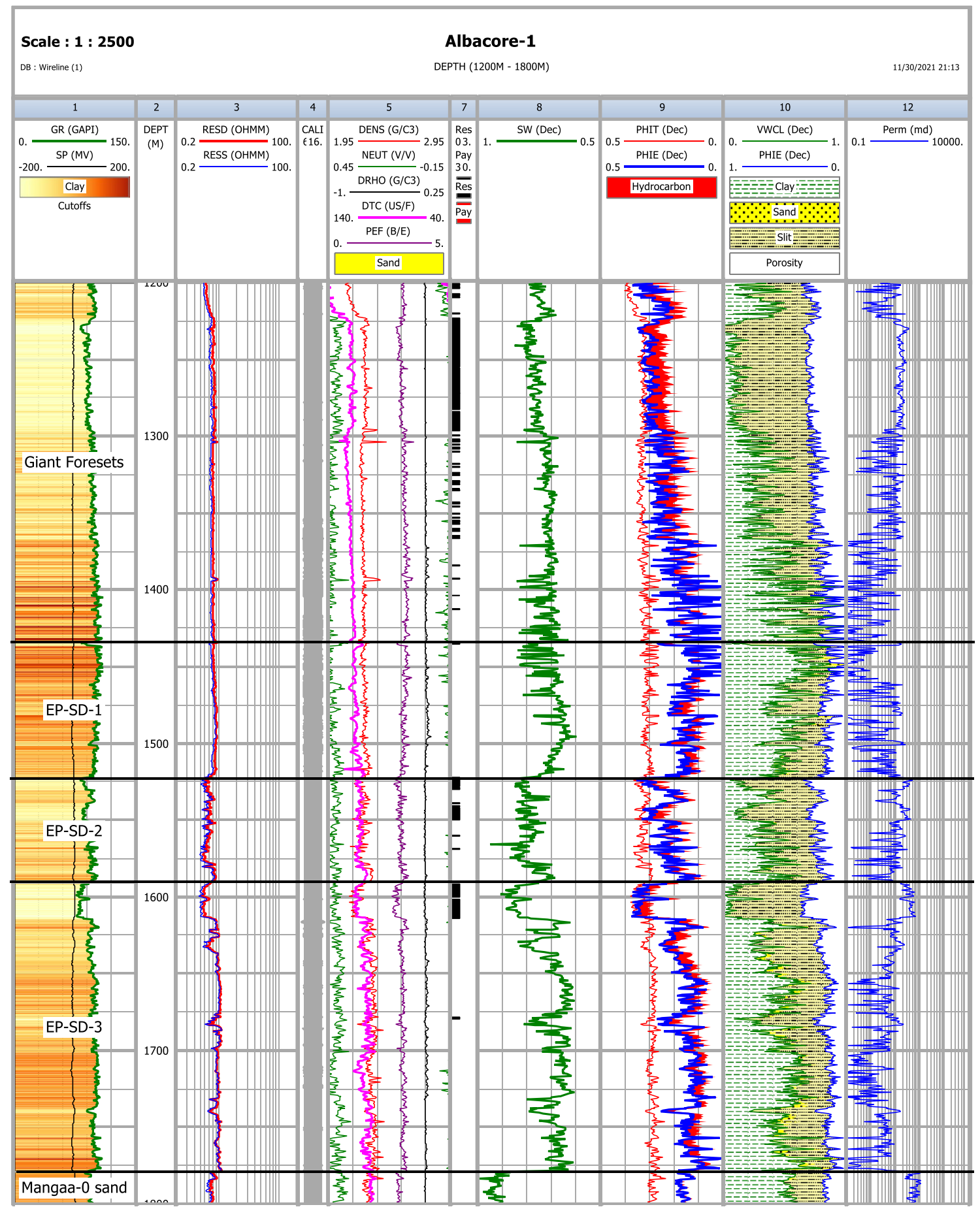

Fig. 3 Litho-saturation cross-plots of the Early Pliocene sandstone (EP-SD) zones showing the porosity, water saturation and the shale volume of the Albacore-1 well

(Fig. 4, Table 2). Also, the petrophysical results indicate that the water saturation $(\mathrm{Sw})$ is relatively high, ranging from $81.4 \%$ at the Mangaa-1 unit to $90.2 \%$ at the Mangaa- 2 unit, while the net/gross ratios of the Mangaa sandstone range from 50.2 to $79.8 \%$.
The study also shows that the Mangaa-0 and Mangaa-2 units are not prospective, while the Mangaa- 1 unit in the middle parts of the Mangaa reservoir sequence is prospective due to the presence of net-pay zone of $5.79 \mathrm{~m}$ thickness (at 2034.5-2044 m depth interval) with hydrocarbon saturation of about $25.6 \%$ (Table 2). The detailed quantitative 


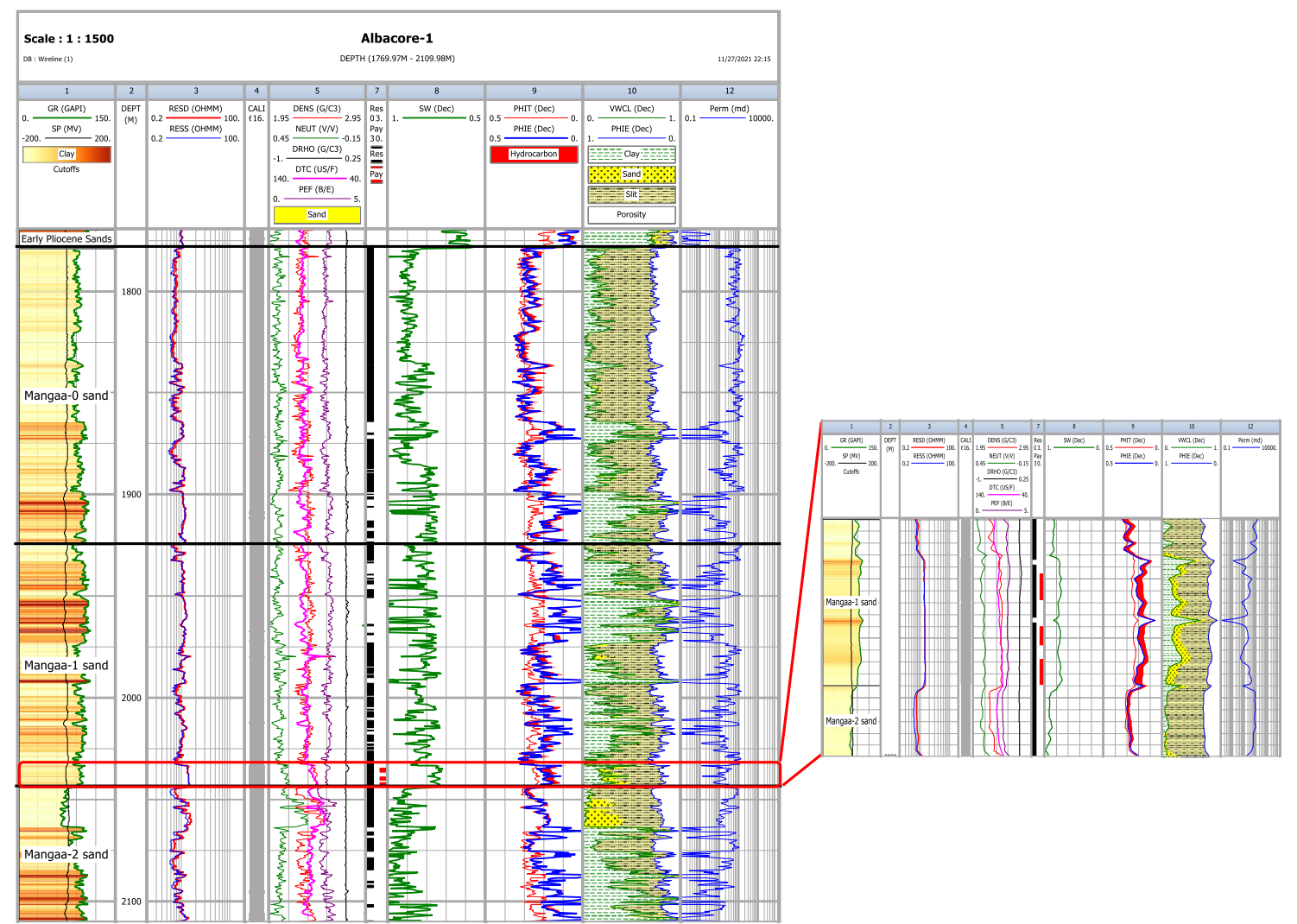

Fig. 4 Litho-saturation cross-plots of the Mangaa Formation showing the porosity, water saturation and the shale volume in addition to the reservoir and pay zones of the Albacore-1 well

Table 2 Quantitative results of the petrophysical analysis of all the identified sand zones, within the Mangaa Formation and through the studied well

\begin{tabular}{|c|c|c|c|c|c|c|c|c|c|c|c|}
\hline Formation & Zone & $\begin{array}{l}\text { Top } \\
\mathrm{m}\end{array}$ & $\begin{array}{l}\text { Bottom } \\
\mathrm{m}\end{array}$ & $\begin{array}{l}\text { NST } \\
\mathrm{m}\end{array}$ & $\begin{array}{l}\text { NRT } \\
\mathrm{m}\end{array}$ & $\begin{array}{l}\text { NPT } \\
\mathrm{m}\end{array}$ & $\mathrm{N} / \mathrm{G}$ & $\begin{array}{l}\varnothing \mathrm{e} \\
\%\end{array}$ & $\begin{array}{l}\text { Vsh } \\
\%\end{array}$ & $\begin{array}{l}\text { Sw } \\
\%\end{array}$ & $\begin{array}{l}\mathrm{S}_{\mathrm{hc}} \\
\%\end{array}$ \\
\hline \multirow[t]{4}{*}{ Mangaa } & Mangaa-0 & 1779 & 1924 & 145 & 115.71 & - & 0.798 & 27.7 & 13.7 & 88.2 & 11.8 \\
\hline & Mangaa-1 & 1924 & 2044 & 120 & 69.89 & 5.79 & 0.582 & 24.5 & 16.9 & 81.4 & 18.6 \\
\hline & Mangaa-2 & 2044 & 2121 & 77 & 38.62 & - & 0.502 & 23.6 & 12.3 & 90.2 & 9.8 \\
\hline & Pay zone & 2034.5 & 2044 & 9.5 & 8.84 & 5.79 & 0.951 & 19.7 & 19.8 & 74.4 & 25.6 \\
\hline
\end{tabular}

NTS is the net sand thickness, NRT is the net reservoir thickness, NPT is the net-pay thickness, N/G is the net to gross, $\varnothing \mathrm{e}$ is the effective porosity, Vsh is the volume of shale, $\mathrm{Sw}$ is the water saturation and $\mathrm{S}_{\mathrm{hc}}$ is the hydrocarbon saturation interpretation of the petrophysical data of the different Mangaa sand units in the studied well (Mangaa-0, Mangaa-1, and Mangaa-2 sand units) are shown in Table 2.

To check the lithological composition and porosity of the studied reservoir sequence, the neutron-density cross-plot was applied. However, shifting the measuring points into higher porosity values on the dolomite line and the relatively high gamma-ray values (50-150 API, Fig. 5a) is primarily attributed to the relatively high content of feldspars and lithic fragments, the very fine sand composition, and the intercalations with many siltstone and mudstone interbeds. Also, following Teama and Nabawy (2016) this shift may be contributed to the effect of increasing the calcareous shale and silt content/interbeds.

The $\mathrm{M}-\mathrm{N}$ cross-plot of the Mangaa reservoir shows that the predominant mineral composition of the Mangaa reservoir is siliciclastic that is represented by very fine argillaceous sand with some siltstone (Fig. 5b).

This achievement is stated by integration with the lithology description, petrography and the XRD data. This integrated data set declares that the measured log responses indicate a predominant very fine siliceous sandstone rich in feldspar and lithic content.

Plotting the porosity versus the water saturation values (Buckles technique, Buckles, 1965; Dewan, 1983; Holmes 

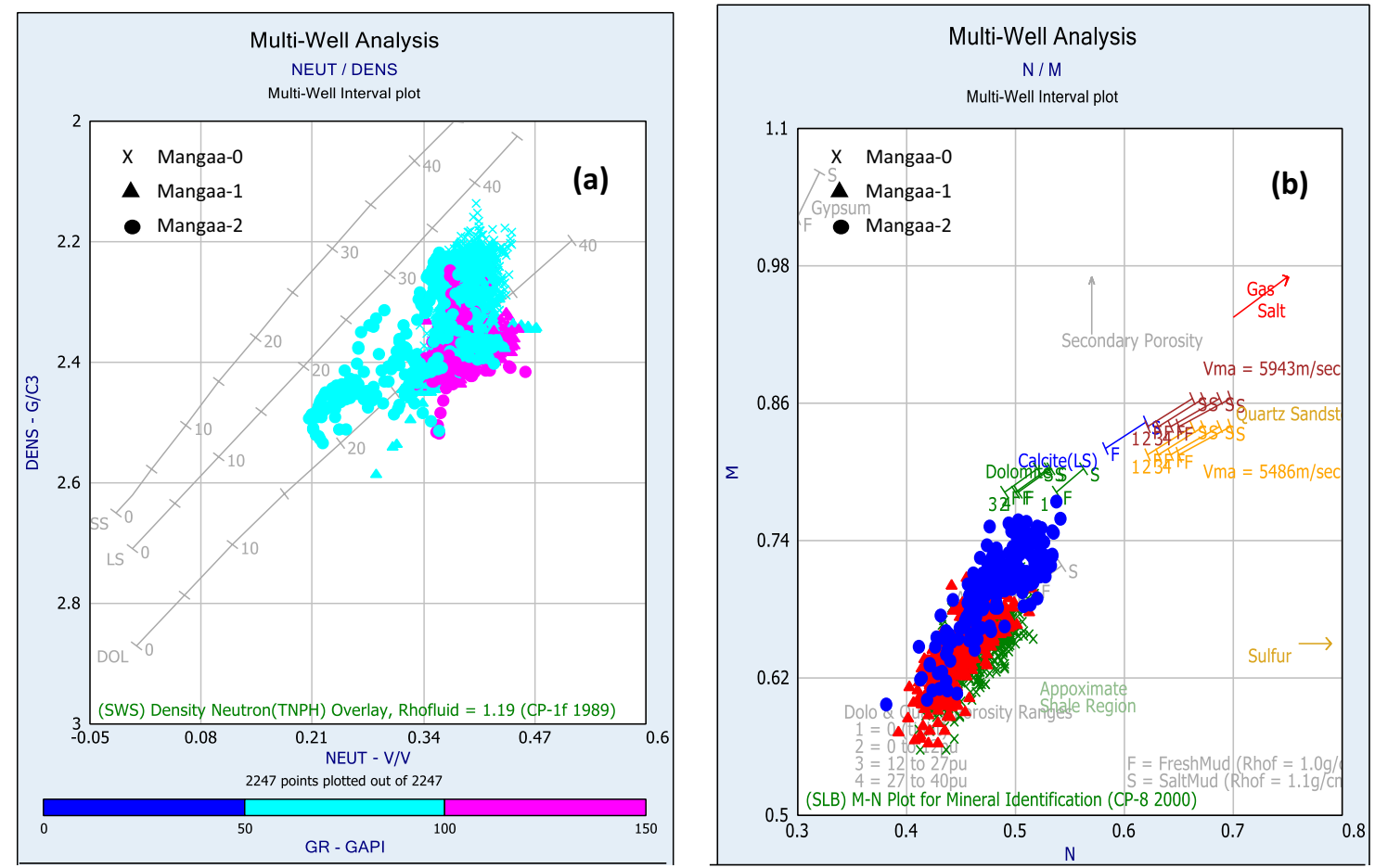

Fig. 5 The X-Y cross-plots of the Mangaa sand units in the Albacore-1 well: a Neutron-Density cross-plot, and b M-N cross-plot

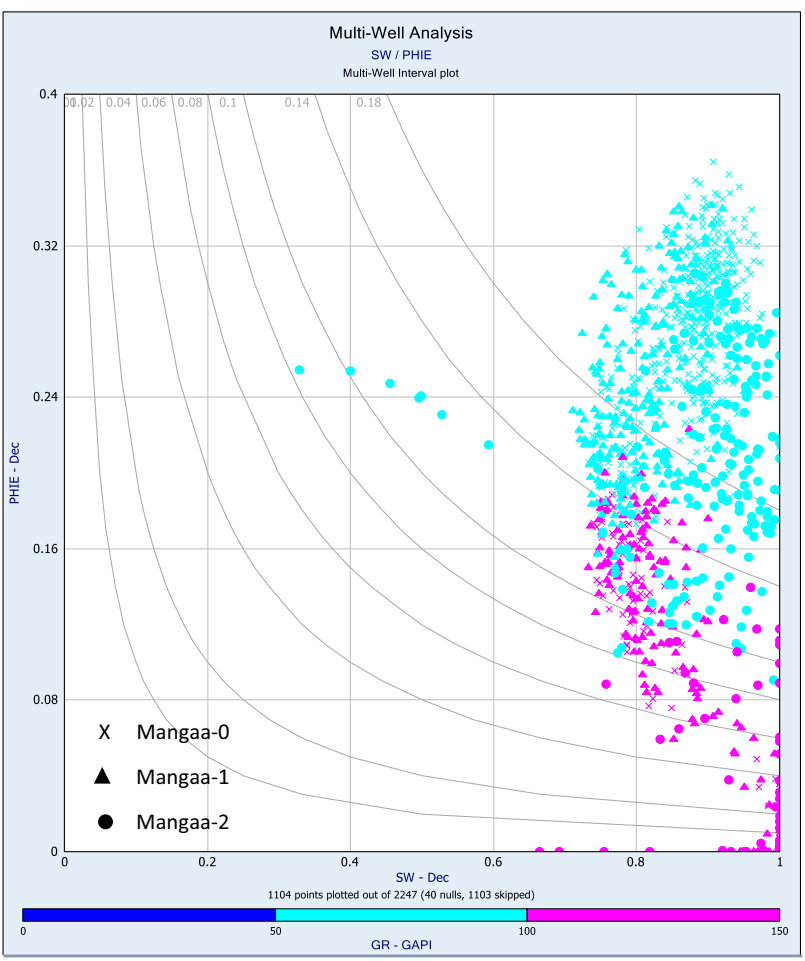

Fig. 6 Applying the Buckles plot as a tool to delineate the water saturation of the Mangaa Formation and its ability to produce hydrocarbons et al., 2009) is a helpful technique for identifying the water saturation and the reservoir rank of the studied depth intervals.

If reservoir is at irreducible water saturation $\left(\mathrm{Sw}_{\mathrm{irr}}\right)$ and exhibits similar bulk volume of water values BVW $(\mathrm{BVW}=\varnothing \mathrm{x} \mathrm{Sw})$ through its different levels, accordingly, the reservoir data points would either cross or be parallel to one of the hyperbolic lines of very low BVW value. If the data points failed to match these criteria, thus the reservoir is not at $\mathrm{Sw}_{\mathrm{irr}}$ (Asquith, 1985; Holmes et al.. 2009; Nabawy et al., 2018b).

It indicates the irreducible water saturation of the given reservoir and the prospectivity of the given reservoir intervals, where higher water saturation and porosity values indicate a lower grain size and reservoir quality, while lower water saturation and high porosity values indicate higher grain size and reservoir quality (Nabawy et al., 2018b; Abuhagaza et al., 2021; Safa et al., 2021).

Shifting from high porosity and low water saturation values (high permeability) to the low porosity-high water saturation values (low permeability), indicates shifting from high to low reservoir quality, from higher to lower permeability. Accordingly, the lowest BVW values indicate the high ability of the reservoir to produce free-water hydrocarbons, whereas the higher BVW values indicate fine sediments and low capability to produce free-water hydrocarbons (Fig. 6). 


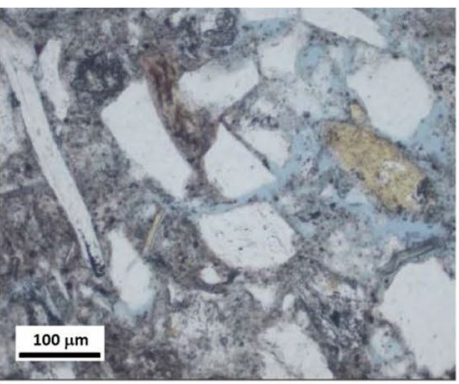

(a)

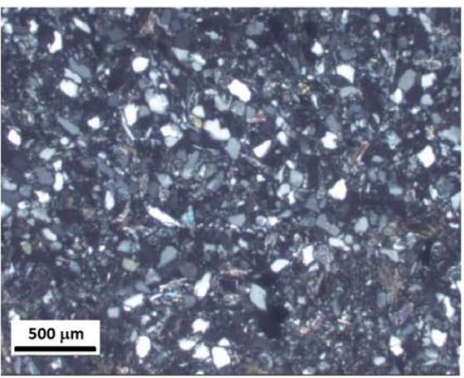

(d)

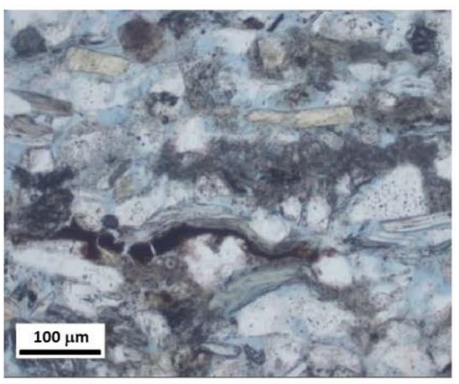

(g)

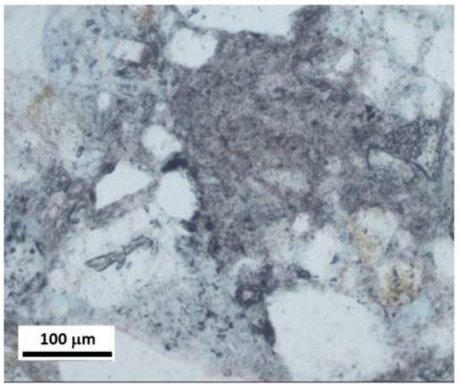

(j)

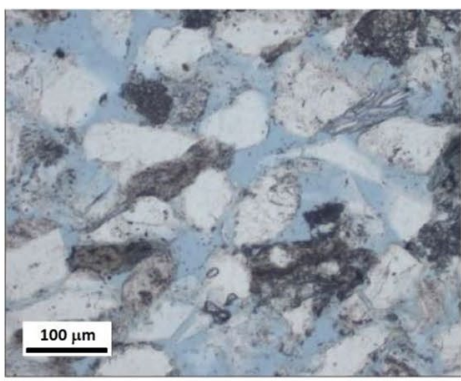

(b)

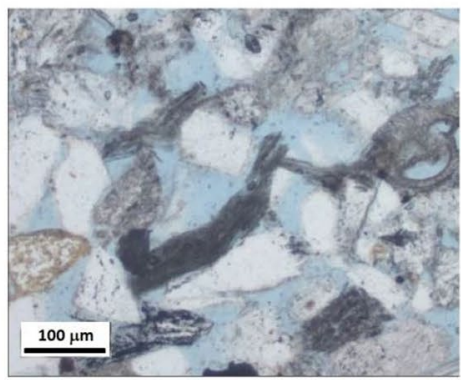

(e)

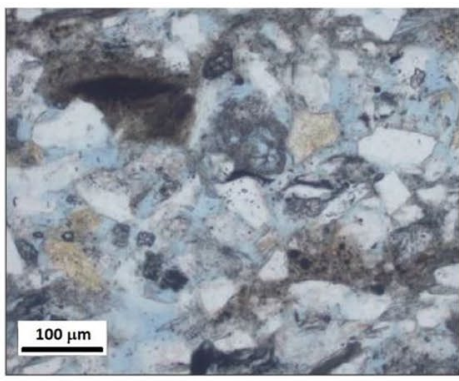

(h)

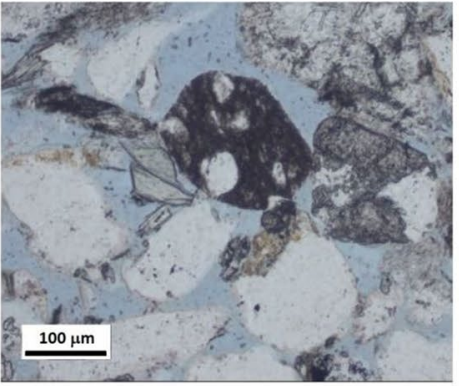

(k)

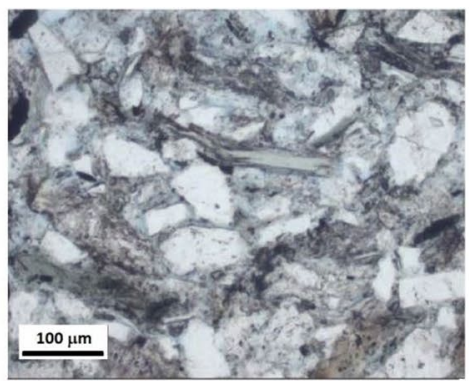

(c)

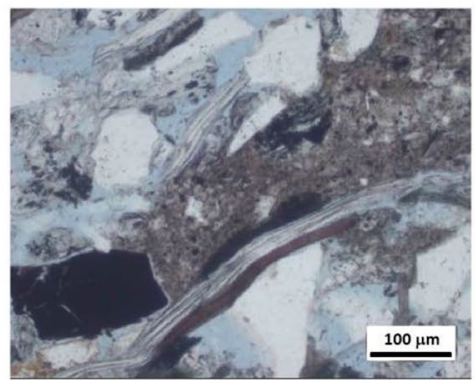

(f)

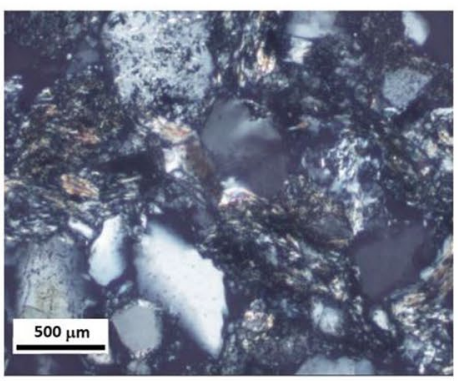

(i)

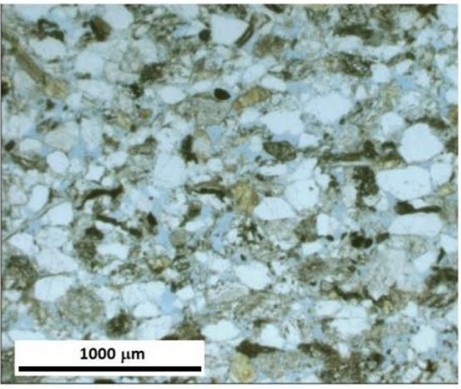

(I)

\section{Microfacies analysis and mineral composition}

The petrological and microfacies analysis of the Mangaa sand reservoir intervals and their discrimination into some microfacies were applied to reveal the mineral composition, the diagenetic features and the reservoir quality to support the well log data analysis. Each microfacies or rock type has its diagnostic features including the pore types, mineral composition, grain-to-grain fabric, and the diagenetic features that can be identified petrographically and considering the XRD data.

\section{Petrographical study}

The studied Mangaa sandstone was studied petrographically and discriminated into some microfacies. Following the sandstone classification and nomenclature of Pettijohn 
4Fig. 7 Photomicrographs of the Mangaa sandstone showing a intergranular connected pore spaces occluded by the clay matrix, PPL, feldspathic greywacke microfacies, $1436.5 \mathrm{~m}$ depth, b some altered lithic fragments of cloudy surfaces with very good effective porosity (dyed blue), PPL, feldspathic greywacke microfacies, $1517.0 \mathrm{~m}$ depth, $\mathbf{c}$ some fine to very fine altered lithic fragments and deformed mica flakes compacted together and embedded in matrix-rich groundmass, PPL, feldspathic greywacke microfacies, $1517.0 \mathrm{~m}$ depth, d very fine grained sandstone embedded in matrix-rich groundmass, XPL, feldspathic greywacke microfacies, $1436.5 \mathrm{~m}$ depth, e some deformed and altered lithics fragments, and mica flakes with a very fine foraminifera test, PPL, micaceous lithic arenite microfacies, $1545.3 \mathrm{~m}$ depth, $\mathbf{f}$ fine to coarse angular grained lithic and wood fragments broken down, bended and embedded in pore-occluding matrix, PPL, micaceous lithic arenite microfacies, $1545.3 \mathrm{~m}$ depth, $\mathbf{g}$ very fine to silt-sized quartz grains well-preserved pores partially filled with some mica flakes, organic materials and silt-sized foraminifera tests embedded in clay matrix, PPL, micaceous lithic greywacke/ siltstone microfacies, $1826.7 \mathrm{~m}$ depth, $\mathbf{h}$ silt-sized quartz grains and a foraminifera test in the center of the image with many connected intergranular pores partially occluded by clay matrix, PPL, micaceous lithic greywacke/siltstone microfacies, $1826.7 \mathrm{~m}$ depth, $\mathbf{i}$ fine to very fine highly altered muddy lithic fragments embedded in silica cement (micro quartz) and clay matrix, XPL, siliceous greywacke microfacies, $1925.2 \mathrm{~m}$ depth, j highly altered medium-grained lithic clast, altered and broken down to clay matrix, PPL, feldspathic and lithic greywacke microfacies, $2045.0 \mathrm{~m}$ depth, $\mathbf{k}$ fine to very fine volcanic fragments with much connected pore spaces, PPL, feldspathic and lithic greywacke microfacies, $2048.0 \mathrm{~m}$ depth, and $\mathbf{l}$ fine to very fine quartz sandstone rich in fresh glauconite pellets with much pore intergranular spaces, PPL, glauconitic lithic arenite microfacies, $2045.0 \mathrm{~m}$ depth

et al. (1987), the Mangaa sandstone can be discriminated into six microfacies (1) feldspathic greywacke, (2) micaceous lithic arenite, (3) micaceous lithic greywacke/siltstone, (4) siliceous greywacke, (5) feldspathic and lithic greywacke, and (6) glauconitic lithic arenite/siltstone microfacies. A detailed description of the mineral composition and fabric of these microfacies are discussed in the following section.

\section{Feldspathic greywacke microfacies}

This microfacies represents the unit EP-SD1 at depth $1436.5 \mathrm{~m}$; it is composed of very fine, well sorted and angular to subangular monocrystalline quartz grains with some potash feldspars and a few lithic fragments, mica flakes, and fine to very fine glauconite pellets that are embedded in clay matrix (Fig. 7a). The lithic fragments are primarily composed of fine grained mudstone and siltstone fragments that often compacted and deformed (Fig. 7b). These muddy clastics seem to be the source of the argillaceous matrix due to their deformation and breakdown. Also, a few foraminifera tests are also observed, while the sparry calcite cement is rarely observed. Mica is represented by some deformed biotite and muscovite flakes (Fig. 7c). Porosity of this microfacies is fair to good
(11.6-19.3\%) and can be described as (1) intergranular pores (dyed blue, Fig. 7a), (2) micro vugs, and (3) matrix porosity. Porosity is mostly occluded by the clay content (Fig. 7d) and rarely by the micro sparry calcite.

\section{Micaceous lithic arenite microfacies}

This microfacies represents the unit EP-SD2 at depth $1545.3 \mathrm{~m}$; it is composed of very fine, well sorted, and angular to subangular monocrystalline quartz grains with common lithic fragments and mica flakes. Besides, a few potash feldspars, plagioclase, and fine to very fine glauconite pellets are embedded in clay matrix (Fig. 7d). The plagioclase is fresh and sometimes is highly altered to sericite. The mica flakes are primarily bended, deformed and altered (Fig. 7e, f). The lithic fragments are frequently of sedimentary origin and composed of fine grained mudstone and siltstone (Fig. 7e). Besides, a few foraminifera tests are recorded but frequently crushed. These phenoclasts are embedded in clay matrix which is mostly related to the crushing and breakdown of the mudstone lithic fragments. It is rich in organic material. Porosity is primarily connected and ranked as good porosity $(19.0 \%)$ and described as (1) intergranular pores, (2) micro to meso vugs (dyed blue, Fig. 7e, f), and (3) matrix porosity. Porosity is mostly deteriorated due to compaction and richness in the mica flakes and clay matrix that occluded the pore volume and bended with the predominated compaction forces (Fig. 7f).

\section{Micaceous lithic greywacke/siltstone microfacies}

This microfacies represents the unit EP-SD3, Mangaa-0, and the Mangaa-1 units at depths $1600.0 \mathrm{~m}, 1826.7 \mathrm{~m}$, and $1996.5 \mathrm{~m}$, respectively; it is composed of silt-sized to very fine, well sorted, and angular monocrystalline quartz grains with common mica flakes and lithic fragments (Fig. $7 \mathrm{~g}$ ). The lithic fragments are fine grained, and frequently altered mudstone fragments, whereas the mica is represented by highly compacted muscovite and biotite flakes that are frequently altered to sericite. Besides, plagioclase, and foraminifera bioclasts are less commonly with traces of altered glauconite pellets, recorded compacted and scattered in a clayey matrix (Fig. 7g). It is rich in organic material. This microfacies has good to very good effective porosity values (19.6-25.6\%) and is described as (1) micro intergranular pores (dyed blue, Fig. $7 g, h$ ), and (2) matrix porosity slightly reduced by clays as patches and filling materials. 


\section{Siliceous greywacke microfacies}

This microfacies represents the Mangaa-1 unit at depth $1925.2 \mathrm{~m}$. It consists of well sorted, very fine to fine, and sub-angular quartz grains, mostly monocrystalline, with some plagioclase, K-feldspars, mica flakes, and lithic fragments (Fig. 7i). The lithic fragments of this microfacies are different from that of the other microfacies and levels, where some fine fragments of metamorphic and igneous origin are recorded in addition to the muddy fragments.

These clasts are commonly altered to clays presented as patches and filling materials. The alteration of this microfacies is sever and extend even to the quartz grains that have pitted surfaces and corroded borders, sometimes presents as grain ghosts (Fig. 7i).

Porosity of this siliceous greywacke microfacies is very good and effective (21.6\%), it is primarily represented (1) micro to meso intergranular pores slightly reduced by clays due to the alteration of the main siliciclasts (Fig. 7), and (2) matrix porosity in between the scattered clay matrix and silica cement.

\section{Feldspathic and lithic greywacke microfacies}

Downward, the Mangaa sandstone mineral composition became more variable in the Mangaa-2 unit with much more diagenesis, lithic and feldspathic content changes. The Mangaa-2 unit at depths $2045.0 \mathrm{~m}$, and $2048 \mathrm{~m}$ is mostly represented by this microfacies which is built of well sorted, very fine to fine, and sub-angular quartz grains, predominantly monocrystalline. It is rich in plagioclase, K-feldspars, and lithic fragments (Fig. 7j). Phenoclasts are frequently altered with pitted surfaces and corroded borders. The lithic fragments are moderately altered and primarily of metamorphic and volcanic in origin (Fig. 7k) with some sedimentary fragments. Alteration increases the amount of the clayey matrix which has been accumulated as patches and shale streaks due to the overload compaction. Mica flakes of this microfacies are less common than the other samples and are represented mostly by very fine muscovite and biotite flakes. Richness in clay content slightly reduced porosity of this microfacies to $17.6 \%$. Pore types are described as (1) micro intergranular pores occluded by the clay matrix (Fig. 7j), and (2) matrix porosity.

\section{Glauconitic lithic arenite microfacies}

It selected from the Mangaa-2 unit at depth $2048.0 \mathrm{~m}$, and composed of very fine to fine grained quartz grains and glauconite pellets with some lithic fragments (Fig. 71). The

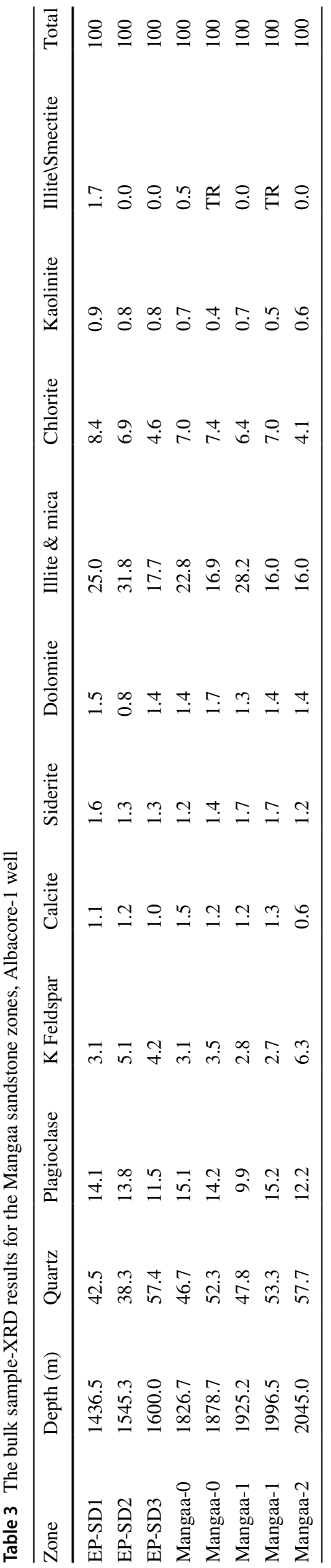


quartz grains are well sorted and angular to sub-angular with clean surfaces. Also, the glauconite pellets are primarily fresh and scattered in between the quarts grains. Most components of this microfacies are fresh; sometimes with a slight alteration giving rise to scattered clay patches that masked few parts of the groundmass and filled the pore spaces. The lithic fragments of this sample are frequently muddy and sub-rounded to rounded due to the relatively distant transportation. Compaction mostly affected the clastic components of this sample, where the grains are in point and side contact situation (Fig. 71). These are commonly altered to clays presented as patches and filling materials. The alteration of this microfacies is sever and extend even to the quartz grains that have pitted surfaces and corroded borders, sometimes presents as grain ghosts (Fig. 7i). It is characterized by very good porosity $(23.3 \%)$ that is represented primarily by (1) well-preserved micro intergranular pores (Fig. 7l), and less frequently (2) matrix porosity.

\section{XRD studies}

The XRD analysis has been applied to confirm the mineral composition results that have been obtained from the petrographical study which indicated that the studied samples are primarily described as very fine sandstone and siltstone that consist of quartz and feldspar grains, in addition to the lithic fragments. This composition is confirmed by the XRD analysis data (Table 3), which shows a predominant quartz composition (38.3\% at EP-SD2 unit up to 57.7\% at Mangaa-2 sand unit), and some plagioclase and K-feldspar content (9.9-15.2\% plagioclase and 2.7-6.3\% K-feldspar, Table 3). Based on the XRD data, it is indicated that the studied sand samples are mostly rich mica/illite (16.0-31.8\%) with some chlorite content $(4.1-8.4 \%)$ and few kaolinite $(0.4-0.9 \%)$ and illite/smectite ( $0-1.7 \%)$. The very low content of the calcite/ dolomite $(<3.1 \%$ for both, Table 3$)$ is primarily due to the presence of few disintegrated foraminifera tests as indicated from the petrographical studies.

It is indicated that the quartz content increases in two cycles with the highest content encountered for the EP-SD3 unit (57.4\%) and the Mangaa-2 unit (57.7\%). This cyclic increase is associated with a cyclic decrease in the mica content as show in Table 3, where the lowest mica content is assigned at the EP-SD3 (17.7\%) and Mangaa-1 and Mangaa-2 (16.0\%).

Based on the XRD data, it is indicated that the petrographically described mudstone lithics are probably composed of silt-sized sandstone, and plagioclase beside to a chlorite and mica, where the clay minerals are not common (Table3). This is a main problem to be solved in the Pliocene sandstones throughout the New Zealand gas reservoirs, which make identifying the sandstones composition is difficult, where in spite of the clay content is relatively low, the GR API values are relatively moderate to high (50-150, Fig. 4). This may be explained by the attributing the API values to the relatively high feldspar content and the presence of intercalation with some thin shale streaks due to the overload stress compaction. However, it was difficult to distinguish authigenic clays from those either within the lithic clasts or in matrix related to the breakdown of the detrital lithic clasts.

\section{Implications of diagenesis on reservoir quality}

The diagenetic processes have either reservoir qualitydeteriorating or enhancing implementation on the reservoir rocks. The reservoir quality-deteriorating features can be discriminated into physical and chemical compaction, cementation, and predominance of authigenic minerals, while the quality enhancing factors can differentiated into dissolution and fracturing as stated in many literature (Nabawy and El Sharawy, 2015; El Sharawy and Nabawy, 2016; El Sawy et al. 2020; Nabawy et al. 2020b; Abuhagaza et al. 2021).

\section{Reservoir quality-deteriorating features}

In this concern, the Pliocene Mangaa sandstone is slightly affected by cementation due to the scarcity of the calcite/ dolomite content and the clay content as indicated from the petrographical study and the XRD data.

Illite and illite/smectite (rich in smectite) are the dominant clay minerals with significant chlorite and only minor kaolinite and traces of sepiolite. Illite, illite/smectite and chlorite are consistent with the phases observed in some of the fine grained lithic clasts (mudstones, siltstones) and also in the degraded plagioclase ghosts. Some minor chlorite may be authigenic and related to the breakdown of biotite mica. There may also be some authigenic component to all of the clay phases, but none is volumetrically significant. It would appear that the compaction of labile clasts has redistributed the clay content into the matrix and intercalated streaks, but there is a little evidence for significant authigenic reprecipitation of clays.

Minor authigenic carbonate is seen in most samples, but also it is volumetrically insignificant and never has low ability to occlude pore spaces. Much calcite is probably in the form of deteriorated foraminifera. No clear diagenetic siderite has been observed, and it seems likely that siderite is present in the altered mudstone clasts. At least some are stained for ferroan calcite, although slightly ferroan dolomite was identified from the XRD data.

Minor authigenic pyrite content is present in most samples but with negligible amounts as confirmed from the $\mathrm{XRD}$ data, and is likely related to the biotite breakdown 
and other labile phases. No evidence was seen for quartz overgrowth.

Since the present burial depth is $1.4-2.0 \mathrm{~km}$, so it was thought that the compaction to has slightly affected the present samples. However, the Mangaa sandstones have undergone a moderate amount of mechanical compaction as indicated from bending and fracturing of the labile mica flakes and the lithic clasts, which have broken down forming the matrix as indicated in the feldspathic greywacke microfacies (Fig. 7c), micaceous lithic arenite microfacies (Fig. 7e, f), and the micaceous lithic greywacke/siltstone microfacies (Fig. $7 \mathrm{~g}$ ). Compaction is also indicated from the wavy extinction of the quart grains as revealed in the micaceous lithic arenite microfacies (Fig. 7f), and the siliceous greywacke microfacies (Fig. 7i). The point contact and long straight grain-to-grain contact confirms a slight mechanical compaction of the feldspathic greywacke microfacies (Fig. 7d), and the glauconitic lithic arenite microfacies (Fig. 71). Besides, it is worthy mentioned that the Mangaa sequence is dissected by many gravity-driven listric growth faults.

\section{Reservoir quality-enhancing features}

Fracturing and dissolution are the common porosity and reservoir quality-enhancing factors in different reservoir rocks (Nabawy and El Aal, 2019; Nabawy et al. 2020a; 2020b). For the present study, dissolution is the most effective diagenetic feature. It seems to compensate the deteriorating implication of compaction on quartz grains, where in spite of the compaction effect, the quartz grains are still float within the matrix and just in grain-to-grain point and straight contact (Fig. 7a:1). Dissolution is indicated by the relatively high visual porosity values (intergranular and vuggy pore spaces, 11.6-25.6\%) and scarcity of cement in the fledspathic greywacke, micaceous lithic arenite, micaceous lithic greywacke/siltstone, siliceous greywacke, feldspathic and lithic greywacke microfacies (Figs. 7a, b, e, f, h, j, k). The corroded borders and pitted surface of the quartz grains are additional confirmation for the dissolution effect that developed on the grain borders and surfaces (Fig. 7i). The scarcity of the clay content as indicated from the XRD (Table 3) though the richness in deteriorated feldspars may be additional indicator that confirms leaching out of the authigenic clays that produced from this feldspars alteration.

Fracturing, on the other hand, is not clearly evident from the petrography due to the absence of cement and dominance of ductile flakes and muddy lithics. This may be attributed to the impact of dissolution and leaching out of the broken constituents. However, implementation of fracturing may be indicated by the presence of some broken wood fragments as in the micaceous lithic arenite microfacies (Fig. 7f), fragmented lithics as in the feldspathic and lithic greywacke microfacies (Fig. 7j), and deteriorated foraminifera tests in the micaceous lithic greywacke/siltstone microfacies (Fig. $7 \mathrm{~g}, \mathrm{~h}$ ).

\section{Seal capacity results}

The seal capacity for the present study has been achieved via measuring the pore throat distribution and its threshold pressure using the MICP technique. Samples were primarily selected representatively for the gas-bearing zones and from seals above the gas-bearing zones at the depths indicated in Table 4 and then their threshold pressures were estimated and their hydrocarbon-sealing efficiency were estimated (Table 4). These tested seals are mostly composed of siltstones and muddy siltstone. The grain

Table 4 Summary of the MICP results of the studied seal samples and the potential hydrocarbon columns/thickness which the seals can retain before leakage

\begin{tabular}{|c|c|c|c|c|c|c|c|c|c|c|c|}
\hline \multirow[t]{2}{*}{ Zone } & \multirow[t]{2}{*}{ Sampling rationale } & \multirow[t]{2}{*}{$\begin{array}{l}\text { Depth } \\
\text { (m) }\end{array}$} & \multirow[t]{2}{*}{$\begin{array}{l}\mathrm{Pc}_{\mathrm{L}} \\
\text { (psia) }\end{array}$} & \multirow[t]{2}{*}{$\begin{array}{l}\mathrm{R}_{35} \\
(\mu \mathrm{m})\end{array}$} & \multirow[t]{2}{*}{$\begin{array}{l}\mathrm{R}_{\text {Mode }} \\
(\mu \mathrm{m})\end{array}$} & \multirow[t]{2}{*}{$\begin{array}{l}\text { Porosity } \\
(\%)\end{array}$} & \multirow[t]{2}{*}{$\begin{array}{l}\mathrm{k} \\
(\mathrm{md})\end{array}$} & \multirow[t]{2}{*}{$\begin{array}{l}\text { Grain density } \\
\left(\mathrm{g} / \mathrm{cm}^{3}\right)\end{array}$} & \multicolumn{2}{|c|}{$\begin{array}{l}\text { Potential } \\
\text { hydrocarbon } \\
\text { columns (m) }\end{array}$} & \multirow[t]{2}{*}{ Lithology } \\
\hline & & & & & & & & & Oil & Gas & \\
\hline EP-SD1 & $\begin{array}{l}\text { seal above } \\
\text { EP-SD2 }\end{array}$ & 1510 & 200.3 & 0.218 & 0.215 & 23.9 & 0.377 & 2.63 & 24.9 & 23.5 & Siltstone \\
\hline EP-SD2 & $\begin{array}{l}\text { seal above } \\
\text { EP-SD3 }\end{array}$ & 1588 & 241.3 & 0.128 & 0.074 & 27.2 & 0.412 & 2.73 & 29.8 & 28.2 & Siltstone \\
\hline EP-SD3 & Mudstone & 1655 & 341.2 & 0.128 & 0.084 & 23.0 & 0.356 & 2.67 & 42.1 & 39.8 & Muddy Siltstone \\
\hline EP-SD3 & seal above Mangaa-0 & 1777 & 341.3 & 0.129 & 0.086 & 20.6 & 0.327 & 2.61 & 42.4 & 40.0 & Muddy Siltstone \\
\hline Mangaa-0 & marl & 1837 & 140.6 & 0.127 & 0.085 & 24.6 & 0.375 & 2.65 & 17.4 & 16.4 & Siltstone \\
\hline Mangaa-0 & seal above Mangaa-1 & 1918 & 346.3 & 0.222 & 0.149 & 23.1 & 0.369 & 2.60 & 43.0 & 40.6 & Muddy Siltstone \\
\hline Mangaa-1 & seal above Mangaa-2 & 2035 & 140.5 & 0.146 & 0.164 & 22.4 & 0.397 & 2.66 & 17.4 & 16.4 & Siltstone \\
\hline
\end{tabular}

$\mathrm{PcL}$ is the threshold pressure measured in the lab, $\mathrm{R}_{35}$ is the pore radius measured at $5 \%$ mercury saturation, $\mathrm{k}$ is the permeability and $\mathrm{R}_{\text {mode }}$ is the more dominant pore radius 

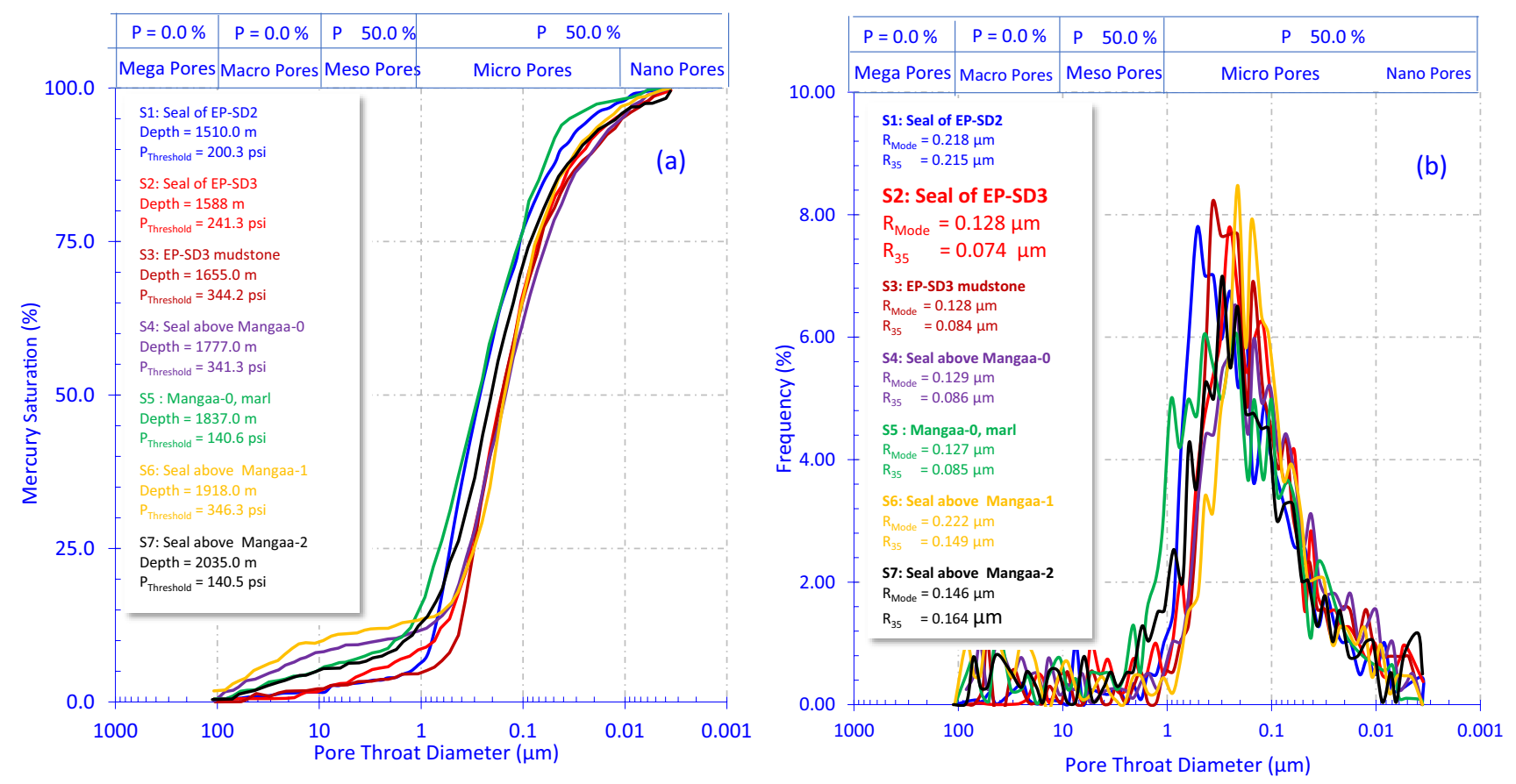

Fig. 8 The mercury injection capillary pressure MICP plots of the studied seals a plotting the mercury saturation as a function of the pore throat diameter, and $\mathbf{b}$ the frequency curve of the pore throat diameter of the studied seal samples

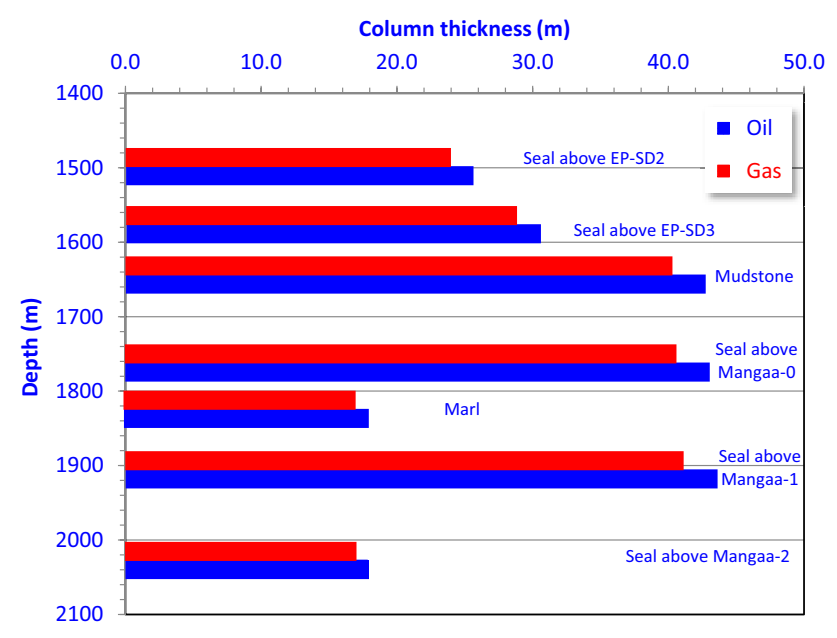

Fig. 9 Seal capacity of the studied EP-SD and Mangaa siltstones and muddy siltstones. Thicknesses of the gas and oil columns are listed in Table 4

density of these samples are ranging from 2.60 to $2.73 \mathrm{~g} /$ $\mathrm{cm}^{3}$; the relatively high grain value of the siltstone of the EP-SD2 sample (seal of EP-SD2) is due to its richness in the mica (muscovite and biotite), chlorite $\left((\mathrm{Mg}, \mathrm{Fe}, \mathrm{Al})_{6}\right.$. $\left.(\mathrm{Si}, \mathrm{Al})_{4} \cdot \mathrm{O}_{10} \cdot(\mathrm{OH})_{8}\right)$, and the siderite $\left(\mathrm{FeCO}_{3}\right)($ Table 3$)$. In the EP-SD2, these constituents reach up to $31.8 \%, 6.9 \%$, and $1.3 \%$ for the mica, chlorite and siderite, respectively (Table 3). The mica content which has a density equals to

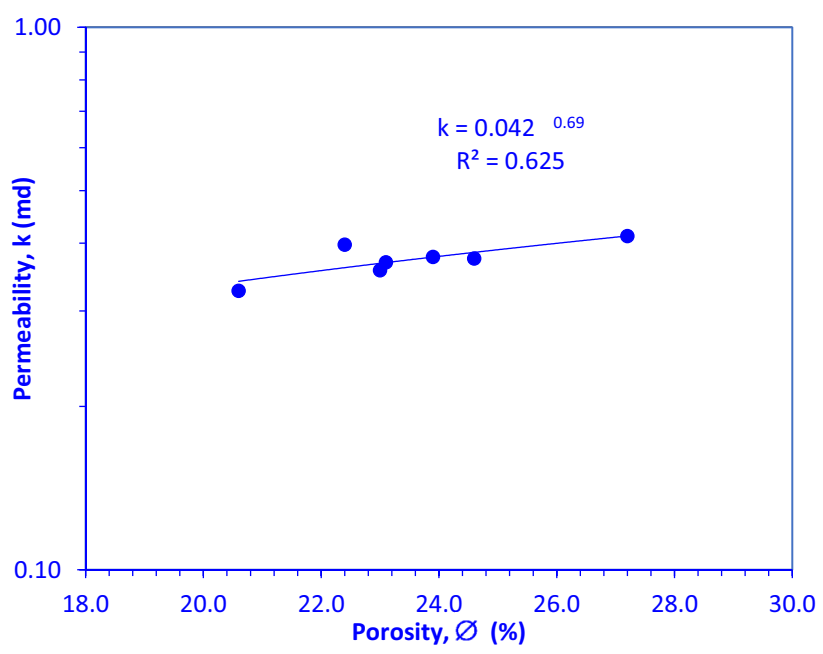

Fig. 10 Permeability values of the studied seals as a function of their porosity

$2.88 \mathrm{~g} / \mathrm{cm}^{3}$, the chlorite content of density may reach up to $3.3 \mathrm{~g} / \mathrm{cm}^{3}$, and the siderite content which has a density equals to $3.96 \mathrm{~g} / \mathrm{cm}^{3}$ due to its iron content. Based on the mercury saturation-pore diameter plot (Fig. 8a), it is indicated that less than $15 \%$ of the pore throats are in the range of meso and macro pore sizes $(1.0-100 \mu \mathrm{m})$, while the predominant pore spaces are in the range of micro and nano pore sizes $(\mathrm{D}<1.0 \mu \mathrm{m})$. Besides, presenting the pore 
throat diameter on a frequency plot indicates dominance of the micro pores $(0.1-1.0 \mu \mathrm{m}$, Fig. $8 \mathrm{~b})$. From this plot, it is also indicated that the $\mathrm{R}_{35}$ (mercury saturation at 35\%) and the $R_{\text {mode }}$ values are in the range of the micro pore spaces with less values for the EP-SD3 mudstone, seal above Mangaa- 0 and the seal above Mangaa-1 (at depths 1655,1777 , and 1918, respectively), i.e., higher efficiency for trapping oil and gas-bearing zones with good thickness (Table 4). This high efficiency is primarily attributed to the siltstone and muddy siltstone composition.

Following the reservoir quality classification of Nabawy et al. (2018b), these samples are tight and may act as seal beds. However, this plot indicates the presence of 5-15\% pore spaces in the size of macro and meso pores which reduces the efficiency of these seal samples. The $R_{35}$ and the $R_{\text {mode }}$ values of the seal above the Mangaa- 0 sand in the EP-SD3 and the mudstone sample of the EP-SD3 to be the best seals in this sequence (Table 4).

The estimated threshold pressure (PcL) for each sample can be used by importing into Eqs. 9 and 10 to estimate the efficiency of these samples to act as seal rocks and to estimate thickness of the gas and oil that can trap. The results of the calculations suggest that the potential hydrocarbon columns, that the sampled seal intervals in Albacore- 1 well could hold $17.4 \mathrm{~m}$ up to $43.0 \mathrm{~m}$ hydrocarbon columns (Table 4, Fig. 9).

Correlating the estimated seal efficiencies (hydrocarbon thicknesses) with that published by Radwan et al. (2022b) indicated that the efficiency of seals in the Mangaa sandstone sequence to the north of Taranki Basin (at the Albacore-1 well) is less effective than that in the central parts of the basin at Karewa Field (reached up to $150 \mathrm{~m}$ and $237 \mathrm{~m}$ of gas and oil thickness at $10 \% \mathrm{Hg}$ saturation, respectively).

To examine the ability of the studied seals to leak the fluids, their permeability values were estimated based on the $\mathrm{R}_{35}$ using the Winland Eq. (1972) and a verified mathematical model has been estimated to calculate permeability of these seals as a function of their porosity as follows.

$\mathrm{k}_{\text {seal }}=0.042\left(\varnothing_{\text {seal }}\right)^{0.69}\left(\mathrm{R}^{2}=0.614\right)(11)$.

Following the rock classification ranks of Abuamarah et al. (2019), the obtained permeability values (0.327-0.412 md, Table 4, Fig. 10) indicate poor permeable rocks $(0.1 \mathrm{md}<$ poor permeable rock $<1.0 \mathrm{md})$. Following this classification good seals are tight permeable rocks $(0.01 \mathrm{md}<$ tight permeable rock $<0.1 \mathrm{md})$, whereas the best seals are in the micro Darcy range (very tight permeable rock $<0.01 \mathrm{md}$ ). Therefore, based on the estimated permeability values of the EP-SD and Mangaa seals, the studied seals are in the range of poor permeability and considered of low potentiality.

\section{Conclusions}

The well log analysis of the studied Miocene-Early Pliocene sequence in north the Taranaki Basin indicates that the Early pliocene sandstone (EP-SD) units are not prospective, while a total of 5.79 m net-pay thickness is assigned in the Upper Miocene-Lower Pliocene Mangaa-1 sandstone unit. This prospective unit has an effective porosity equals $19.7 \%$, shale volume equals $19.8 \%$ and hydrocarbon saturation about $25.6 \%$. Besides, the Buckles plot indicates that, in spite of the relatively low reservoir quality in north Taranaki Basin, the BVW values $>0.18$ for about $75 \%$ of the total estimated points. This indicates that the Mangaa sandstone units will primarily produce water with low hydrocarbons production.

The petrographical studies indicate that the studied Late Miocene-Early Pliocene zones are composed of very fine greywackes and lithic arenites/siltstones rich in feldspars, chlorite and mica. The mechanical compaction is the predominant reservoir quality-deteriorating factor. However, dissolution and leaching of the dissolved and altered components reduced the compaction implementation on the reservoir quality of the Mangaa sandstone units.

The (MICP) results of the seal beds above the different sand units indicate the presence of relatively low threshold pressures that can potentially hold only moderate hydrocarbon columns (not more than $43.0 \mathrm{~m}$ ), which would imply poor to moderate seals. These low values are to be expected given that most of the potential seal units are siltstones and muddy siltstones but neither mudstones nor evaporites.

Therefore, the present study reveals that only a Mangaa-1 sandstone unit is considered prospective unit $(5.79 \mathrm{~m})$ with micaceous and lithic arenite and greywacke composition with some chlorite and feldspars content. Its hydrocarbon charge is sealed by the muddy siltstone of the overlying Mangaa- 0.

Acknowledgements The author would like to thank GNS Science for providing the data and information necessary for this research. The author is also grateful to New Zealand Petroleum \& Minerals and West Energy New Zealand, for generously providing the datasets and the permission for publishing. The authors thanks the Editor-in-Chief Prof. Dr Turgay Ertekin and the anonymous for their valuable and constructive comments that improved and reconstructed the present manuscript.

Funding No funding was received for this study.

\section{Declarations}

Conflicts of interests The authors declare that they have no known competing financial interests or personal relationships that could have appeared to influence the work reported in this paper. 
Open Access This article is licensed under a Creative Commons Attribution 4.0 International License, which permits use, sharing, adaptation, distribution and reproduction in any medium or format, as long as you give appropriate credit to the original author(s) and the source, provide a link to the Creative Commons licence, and indicate if changes were made. The images or other third party material in this article are included in the article's Creative Commons licence, unless indicated otherwise in a credit line to the material. If material is not included in the article's Creative Commons licence and your intended use is not permitted by statutory regulation or exceeds the permitted use, you will need to obtain permission directly from the copyright holder. To view a copy of this licence, visit http://creativecommons.org/licenses/by/4.0/.

\section{References}

Abd El-Gawad EA (2007) The use of well logs to determine the reservoir characteristics of Miocene rocks at the Bahar North East field, Gulf of Sues. Egypt J Pet 30(2):175-188. https://doi. org/10.1111/j.1747-5457.2007.00175.x

Abdelwahhab MA, Radwan AA, Mahmoud H, Mansour A (2022) Geophysical 3Dstatic reservoir and basin modeling of a Jurassic estuarine system (JG-Oilfield, Abu Gharadig basin, Egypt). J Asian Earth Sci. https://doi.org/10.1016/j.jseaes.2021.105067

Abuamarah BA, Nabawy BS, Shehata AM, Kassem OMK, Ghrefat $H$ (2019) Integrated geological and petrophysical characterization of oligocene deep marine unconventional poor to tight sandstone gas reservoir. Mar Pet Geol 109:868-885. https://doi. org/10.1016/j.marpetgeo.2019.06.037

Abuamarah BA, Nabawy BS (2021) A proposed classification for the reservoir quality assessment of hydrocarbon-bearing sandstone and carbonate reservoirs: a correlative study based on different assessment petrophysical procedures. J Nat Gas Sci Eng 88:103807

Abuhagaza AA, El Sawy MZ, Nabawy BS (2021) Integrated petrophysical and petrographical studies for characterization of reservoirs: a case study of Muglad Basin. North Sudan Environ Earth Sci 80:171. https://doi.org/10.1007/s12665-021-09489-7

Archie GE (1942) The electrical resistivity log as an aid in determining some reservoir characteristics. Trans AIME 146(01):54-62

Armstrong PA, Chapman DS, Funnell R, Allis RG, Kamp PJ (1996) Thermal modeling and hydrocarbon generation in an activemargin basin: Taranaki Basin, New Zealand. Am Assoc Pet Geol Bull 80(8):1216-1241

Asquith G, Gibson C (1982) Basic Well Log Analysis for Geologists. The American Association of Petroleum Geologists.

Asquith GB (1985) Handbook of Log Evaluation Techniques for Carbonate Reservoirs. Methods in Exploration Series No. 5. The American Association of Petroleum Geologists Tulsa, Oklahoma, USA. 1-47

Azeem T, Chun WY, MonaLisa, et al (2017) An integrated petrophysical and rock physics analysis to improve reservoir characterization of Cretaceous sand intervals in Middle Indus Basin. Pakistan J Eng 14(2):212-225. https://doi.org/10.1088/1742$2140 / 14 / 2 / 212$

Benaafi M, Mustafa H, Abdulaziz A, Osman A, Mohammed M (2018) Integrated geomechanical, petrographical and petrophysical study of the sandstones of the Wajid Group, SW Saudi Arabia. J Afr Earth Sc 143:162-177. https://doi.org/10.1016/j. jafrearsci.2018.03.011

Buckles RS (1965) Correlating and averaging connate water saturation data. J Can Pet Technol 4(01):42-52. https://doi.org/10. 2118/65-01-07

Chihi H, Bedir M, Belayouni H (2013) Variogram Identification Aided by a Structural Framework for Improved Geometric
Modeling of Faulted Reservoirs: Jeffara Basin. Southeastern Tunisia Nat Res Res 22(2):139-161

Dewan JT (1983) Essentials of modern open-hole log interpretation. PennWell Books, PennWell Publishing Company, Tulsa, Oklahoma, $361 \mathrm{p}$

Dewhurst DN, Jones RM, Raven MD (2002) Microstructural and petrophysical characterization of Muderong Shale: application to top seal risking. Pet Geosci 8(4):371-383

El Sharawy MS, Nabawy BS (2016) Geological and Petrophysical Characterization of the Lower Senonian Matulla Formation in Southern and Central Gulf of Suez. Egypt Arabian J Sci Eng 41(1):281-300

Funnell RH, Stagpoole VM, Nicol A, Killops SD, Reyes AG, Darby D (2001) Migration of oil and gas into the Maui Field, Taranaki Basin, New Zealand. Institute of Geological and Nuclear Sciences, PO Box 30-368, Lower Hut, New Zealand

Ghanizadeh A, Clarkson CR, Aquino S, Ardakani OH, Sanei H (2015) Petrophysical and geomechanical characteristics of Canadian tight oil and liquid-rich gas reservoirs: II. Geomechanical Property Estimation Fuel 153:682-691. https://doi.org/ 10.1016/j.fuel.2015.02.113

Hannon N (1987) Subsurface Water Flow Patterns in the Canadian Sector of the Williston Basin: RMAG 1987 Symposium Guidebook, 313-321

Harrison C, Dutton SP (1991) Reservoir Characterization of the Frontier Tight Gas Sand, Green River Basin. Paper presented at the Low Permeability Reservoirs Symposium, Denver, Colorado, April 1991.Paper Number: SPE-21879-MS. https://doi. org/10.2118/21879-MS

Holmes M, Holmes D, Holmes A (2009) Relationship between Porosity and Water Saturation: Methodology to Distinguish Mobile from Capillary Bound Water. AAPG Annual Convention, Denver, Colorado June 7-10, article 110108.

Isaac MJ, Herzer RH, Brook FJ, Haywood BW (1994) Cretaceous and Cenozoic sedimentary basins of Northland, New Zealand. Lower Hutt, Instit Geol Nuclear Sci Monograph 8:203

Islam MA (2010) Petrophysical Evaluation of Subsurface Reservoir Sandstones of Bengal Basin, Bangladesh. J Geol Soc India 76:621-631

Jadoon K, Roberts E, Blenkinsop T, Wust R, Shah S (2016) Mineralogical modelling and petrophysical parameters in Permian gas shales from the Roseneath and Murteree formations, Cooper Basin. Australia. Petrol Exploration Develop 43(2):253-260

King PR (2000) Tectonic reconstructions of New Zealand 40 Ma to the present. N Z J Geol Geophys 43:611-638

King PR, Thrasher GP (1996) Cretaceous-Cenozoic geology and petroleum systems of the Taranaki Basin, New Zealand. Institute of Geological and Nuclear Sciences monograph 13. 244 p, Lower Hutt, New Zealand: Institute of Geological \& Nuclear Sciences

King PR (1988) Well Summary Sheets, Onshore Taranaki. New Zealand Geological Survey Report G125-G127.

Knox G (1982) Taranaki Basin, structural style and tectonic setting. NZ J Geol Geophys 25:125-140. https://doi.org/10.1080/00288 306.1982.10421405

Larionov VV (1969) Borehole radiometry: Moscow. Nedra, U.S.S.R.

Makhloufi Y, Collin PY, Bergerat F, Casteleyn L, Claes S, David C, Menendez B, Monna F, Robion P, Sizun JP, Swennen R, Rigollet C (2013) Impact of sedimentology and diagenesis on the petrophysical properties of a tight oolitic carbonate reservoir. The case of the Oolithe Blanche Formation (Bathonian, Paris Basin, France). Mar Pet Geol 48:323-340

Molenaar N, Felder M, Bär K, Götz AE (2015) What classic greywacke (litharenite) can reveal about feldspar diagenesis: An example from Permian Rotliegend sandstones in Hessen. Germany Sediment Geol 326:79-93

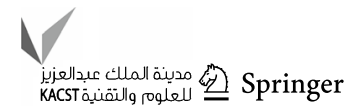


Murray D, de Bock JF (1996) Awatea-1 Well Completion Report, PEP38457. New Zealand Unpublished Openfile Petroleum Report, 2262, 1390p., 33 enclosures

Nabawy BS, El Aal AA (2019) Impacts of the petrophysical and diagenetic aspects on the geomechanical properties of the dolomitic sequence of Gebel El-Halal, Sinai. Egypt Bull Eng Geol the Environ 78:2627-2640. https://doi.org/10.1007/s10064-018-1264-z

Nabawy BS, El Sharawy MS (2018) Reservoir assessment and quality discrimination of Kareem Formation using integrated petrophysical data, Southern Gulf of Suez. Egypt Marine Petrol Geol 93:230-246

Nabawy BS, Shehata MA (2015) Integrated petrophysical and geological characterization for the Sidi Salem-Wakar sandstones, offshore Nile Delta. Egypt, J African Earth Sci 110:160-175

Nabawy BS, Wassif NA (2017) Effect of the mineralogical composition on the petrophysical behavior of the amygdaloidal and vesicular basalt of Wadi Wizr, Eastern Desert. Egypt J Afr Earth Sci 134:613-625

Nabawy BS, Sediek KN, Nafee SA (2015) Pore fabric assignment using electrical conductivity of some Albian-Cenomanian sequences in north Eastern Desert. Egypt Arabian J Geosci 8(8):5601-5615

Nabawy BS, Rashed MA, Mansour AS, Afify WSM (2018a) Petrophysical and microfacies analysis as a tool for reservoir rock typing and modeling: Rudeis Formation, off-shore October Oil Field, Sinai. Mar Pet Geol 97:260-276

Nabawy BS, Basal AMK, Sarhan MA, Safa MG (2018b) Reservoir zonation, rock typing and compartmentalization of the TortonianSerravallian sequence, Temsah Gas Field, offshore Nile Delta. Egypt Marine Petrol Geol 92:609-631

Nabawy BS, Elgendy NTH, Gazia MT (2020a) Mineralogic and Diagenetic Controls on Reservoir Quality of Paleozoic Sandstones, Gebel El-Zeit, North Eastern Desert. Egypt Nat Res Res 29:1215-1238

Nabawy BS, Mansour AS, Rashed MA, Afify WSM (2020b) Implementation of sedimentary facies and diagenesis on the reservoir quality of the Aquitanian-Burdigalian Rudeis Formation in the Gulf of Suez, Egypt: A comparative surface and subsurface study. Geol J 55(6):4543-4563

Nabawy BS, El Sharawy MS (2015) Hydrocarbon potential, structural setting and depositional environments of Hammam Faraun Member of the Belayim Formation, Southern Gulf of Suez Egypt. J African Earth Sci 112:93-110

Palmer JA (1985) Pre-miocene lithostratigraphy of Taranaki basin, New Zealand. N Z J Geol Geophys 28:197-216

Palmer J, Geoff B (1991) Taranaki Basin, New Zealand. Active Margin Basins, AAPG Memoir 52:261-282

Pettijohn FJ, Potter PE, Siever R (1987) Sand and sandstones, 2nd edn. Springer-Verlag; New York, Berlin, Heidelberg, London, Paris, Tokyo

Pickett GR (1972) Practical formation evaluation. GR Pickett Inc, Golden Colorado

Pilaar WFH, Wakefield LL (1978) Structural and stratigraphic evolution of the Taranaki Basin, offshore North Island, New Zealand. J Australian Petrol Prod Exploration Assoc (APPEA) 18(1):93-101

Poupon A, Leveaux J (1971) Evaluation of water saturation in shaly formations. In: Proceedings of the SPWLA $12^{\text {th }}$ Annual Logging Symposium

Poupon A, Clavier C, Dumanoir J, Gaymard,R, Misk A (1970) Log analysis of sand-shale sequences-A systematic approach. SPE 2897

Radwan AA, Nabawy BS, Abdelmaksoud A, Lashin A (2021a) Integrated sedimentological and petrophysical characterization for clastic reservoirs: A case study from New Zealand. J Nat Gas Sci Eng 88:103797

Radwan AE, Nabawy BS, Kassem AA, Hussein WS (2021b) Implementation of Rock Typing on Waterflooding Process During
Secondary Recovery in Oil Reservoirs: A Case Study, El Morgan Oil Field, Gulf of Suez. Egypt Nat Res Res 30:1667-1696

Radwan AA, Abdelwahhab MA, Nabawy BS, Mahfouz KH, Ahmed MS (2022a) Facies analysis-constrained geophysical 3D-static reservoir modeling of Cenomanian units in the Aghar Oilfield (Western Desert, Egypt): insights into paleoenvironment and petroleum geology of fluviomarine systems. Mar Pet Geol 136:105436

Radwan AA, Nabawy BS, Shihata M, Leila M (2022b) Seismic interpretation, reservoir characterization, gas origin and entrapment of the Miocene-Pliocene Mangaa C sandstone, Karewa Gas Field, North Taranaki Basin, New Zealand. Mar Pet Geol 135:105420

Safa MG, Nabawy BS, Basal AMK, Omran MA, Lashin A (2021) Implementation of a Petrographical and Petrophysical Workflow Protocol for Studying the Impact of Heterogeneity on the Rock Typing and Reservoir Quality of Reefal Limestone: A Case Study on the Nullipore Carbonates in the Gulf of Suez. Acta Geologica Sinica (english Edition) 95(5):1746-1762

El Sawy MZ, Abuhagaza AA, Nabawy BS, Lashin A (2020) Rock typing and hydraulic flow unitsas a successful tool for reservoir characterization of Bentiu-Abu Gabra sequence, Muglad basin, southwest Sudan. J Afr Earth Sci 171:103961

Schlumberger (1989) Cased hole log interpretation principles/applications. Sugar Land, Texas, Schlumberger Educational Services, $198 \mathrm{p}$

Schlumberger (1991) Log interpretation principles/applications. Sugar Land, Texas, Schlumberger Educational Services, $226 \mathrm{p}$

Shalaby MR, Hakimi MH, Abdullah WH (2013) Diagenesis in the Middle Jurassic Khatatba Formation sandstones in the Shoushan Basin, northern Western Desert. Geol J 49(3):239-255

Shalaby MR, Hakimi MH, Abdullah WH (2014) Petroleum system analysis of the Khatatba Formation in the Shoushan Basin, north Western Desert. Egypt Arab J Geosci 7(10):4303-4320

Sutherland R, King P, Wood R (2001) Tectonic evolution of Cretaceous rift basins in southeastern Australia and New Zealand: Implications for exploration risk assessment. Eastern Australia Basins Symposium, Melbourne, PESA, 3-14

Teama MA, Nabawy BS (2016) Petrophysical evaluation of the hydrocarbon potential of the Lower Cretaceous Kharita clastics, North Qarun oil field, Western Desert. Egypt J African Earth Sci 121:62-71

Tiab D, Donaldson EC (2015) Petrophysics: theory and practice of measuring reservoir rock and fluid transport properties, 4th edn. Gulf Professional Publishing, Houston, Elsevier Inc., p 894

Uruski CI, Wood RA (1991) A new look at the New Caledonia Basin, an extension of the Taranaki Basin, North Island. New Zealand Marine Petrol Geol 8(4):379-391

Uruski Ch, Baillie P, Stagpoole V (2003) Development of the Taranaki Basin and comparisons with the Gippsland Basin: implications for deepwater exploration. APPEA J 43(1):185-196

Uruski CI (2000) Petroleum potential of New Zealand's deepwater basins. Proceedings of the 200 New Zealand Petroleum Conference March 19-22, Christchurch. Crown Minerals Ministry of Economic Development, Wellington. 146-52

Vavra CL, Kaldi JG, Sneider RM (1992) Geological applications of capillary pressure: a review. AAPG Bull 76:840-850

Winland HD (1972) Oil accumulation in response to pore size changes, Weyburn field, Saskatchewan. Amaco Production Research Report No. F72-G-25

Publisher's Note Springer Nature remains neutral with regard to jurisdictional claims in published maps and institutional affiliations. 